\title{
23. UPPER QUATERNARY VEGETATION AND CLIMATE HISTORY OF THE AMAZON BASIN: CORRELATING MARINE AND TERRESTRIAL POLLEN RECORDS ${ }^{1}$
}

\author{
Simon Haberle ${ }^{2}$
}

\begin{abstract}
Pollen analysis of 37 samples from the Amazon Fan (Sites 930, 931, 932, 936, 938, and 946) show changes in pollen frequencies that may reflect vegetational changes in the Amazon Basin through at least the last 105 k.y. Through most of the records, the relative percentages of pollen and spores exhibit fluctuations that correspond to cyclic changes in climate and sea level. Comparisons with modern Amazon River pollen assemblages suggest that the increase in cold-adapted arboreal taxa such as Podocarpus, Alnus, and Hedyosmum, throughout the last glacial, peaking between 21,000 and 17,000 BP, may represent an expanded distribution of these taxa within the basin in response to a colder climate. Between 36,000 and 28,000 BP, coldadapted taxa show reduced percentage representations, comparable to levels found in postglacial samples, suggesting a contraction of these taxa in response to a warmer climate. The pollen record suggests that there are only moderate changes in the extent of savanna at times of fluctuating temperature during the last glacial period. This highlights the complex interaction of controlling factors such as precipitation, temperature, and atmospheric $\mathrm{CO}_{2}$ for historical plant distribution in the lowland Amazon Basin as well as in the Andes.
\end{abstract}

\section{INTRODUCTION}

Despite the importance of the Amazon Basin to understanding the development of complex vegetation communities on a Quaternary time scale, there have been very few paleoecological studies within forested catchments in the basin. The sites that are available are widely dispersed, poorly constrained in time, and often open to a wide range of interpretation. Palynological studies of marine sediments adjacent to the Amazon Basin potentially can provide important proxy records for terrestrial vegetation and climate change as has been previously demonstrated in other regions of substantial biogeographic interest (Heusser and Shackleton, 1994; Hooghiemstra et al., 1992; Kershaw et al., 1993). The Amazon Fan, a large mud-rich deposit built of mainly terrigenous sediments supplied from the catchment of the Amazon River, represents just such an environment that may provide proxy records for terrestrial vegetation and climate change in the Amazon Basin. This study incorporates suspended sediment samples from the Amazon River, mud samples dated to within the last $5 \mathrm{k} . \mathrm{y}$. from the adjacent continental shelf, and Ocean Drilling Program (ODP) Leg 155 samples collected from the Amazon Fan. The aim of this study is to (1) improve our understanding of pollen transport and sedimentation processes to the Amazon Fan, (2) attempt correlation with terrestrial pollen records and oxygen isotope variations in order to assess the regional extent and nature of vegetation and climate change in the Amazon Basin during the upper Quaternary, and (3) contribute to the debate over the extent of fragmentation of closed forest cover and hence intensity of aridity during the glacial period (Colinvaux, 1987; Van der Hammen and Absy, 1994).

This paper adopts the terms "glacial" and "interglacial" to refer to periods of low or high sea level or relatively cold and warm climate during the Quaternary, respectively. The oxygen isotope chronostratigraphy of Martinson et al. (1987) shows that the most recent cold phase peaked at $\sim 18,000 \mathrm{BP}$, when the sea level was at its

'Flood, R.D., Piper, D.J.W., Klaus, A., and Peterson, L.C. (Eds.), 1997. Proc. ODP, Sci. Results, 155: College Station, TX (Ocean Drilling Program).

${ }^{2}$ Smithsonian Tropical Research Institute, Box 2072, Balboa, Republic of Panama. lowest, and is referred to here as the "last glacial maximum" (LGM). The present interglacial, or "postglacial" (oxygen isotope Stage 1), and the "last interglacial" between Substages 5.51 and 5.53, represent the warmest periods when the sea level was at its highest.

\section{GEOGRAPHICAL SETTING}

The Amazon Fan extends more than $700 \mathrm{~km}$ seaward of the continental shelf and is a typical passive-margin deep-sea fan (Stow et al., 1985). The Amazon River has supplied sediment to the area since the upper Miocene when the upheaval of the Andean mountain chain diverted drainage eastward to form the present-day Amazon drainage basin (Hoorn et al., 1995). During interglacial high sea-level conditions, the submerged continental shelf is characterized by energetic physical processes, including strong tidal currents, prolonged southeasterly trade winds and the North Brazil Coastal Current that sweep Amazon River sediments north westwards, preventing these sediments from crossing the submerged shelf (Geyer et al., 1991; Nittrouer et al., 1995). During glacial low sea levels, river sediment is deposited directly to the fan through a submarine canyon. Sediment aggradation is characterized by high sedimentation rates (typically $3-8 \mathrm{~m} /$ k.y.) in prograding channel-levee complexes. The silty clay to clay deposits found in the channel-levee complexes are dominantly terrigenous in origin and are the focus of sampling for this investigation. Samples were taken from six sites located at different water depths and latitude across the fan (Fig. 1), and detailed sampling of two sites, Holes 932A and 946A, provides the opportunity to study the spatial and temporal variations in pollen assemblage composition across the fan.

The source of suspended sediment transported by the Amazon River, the largest river in the world in terms of water discharge, is found within a catchment area of $6.9 \times 10^{6} \mathrm{~km}^{2}$ that extends some $5000 \mathrm{~km}$ from the eastern slope of the Andes to the Atlantic Ocean. Most suspended sediment is derived from the tributaries draining the Andes, where high rainfall and steep slopes contribute to the release of stored sediment (Meade, 1994). Understanding the nature of transport processes operating between the source of pollen and spores to 


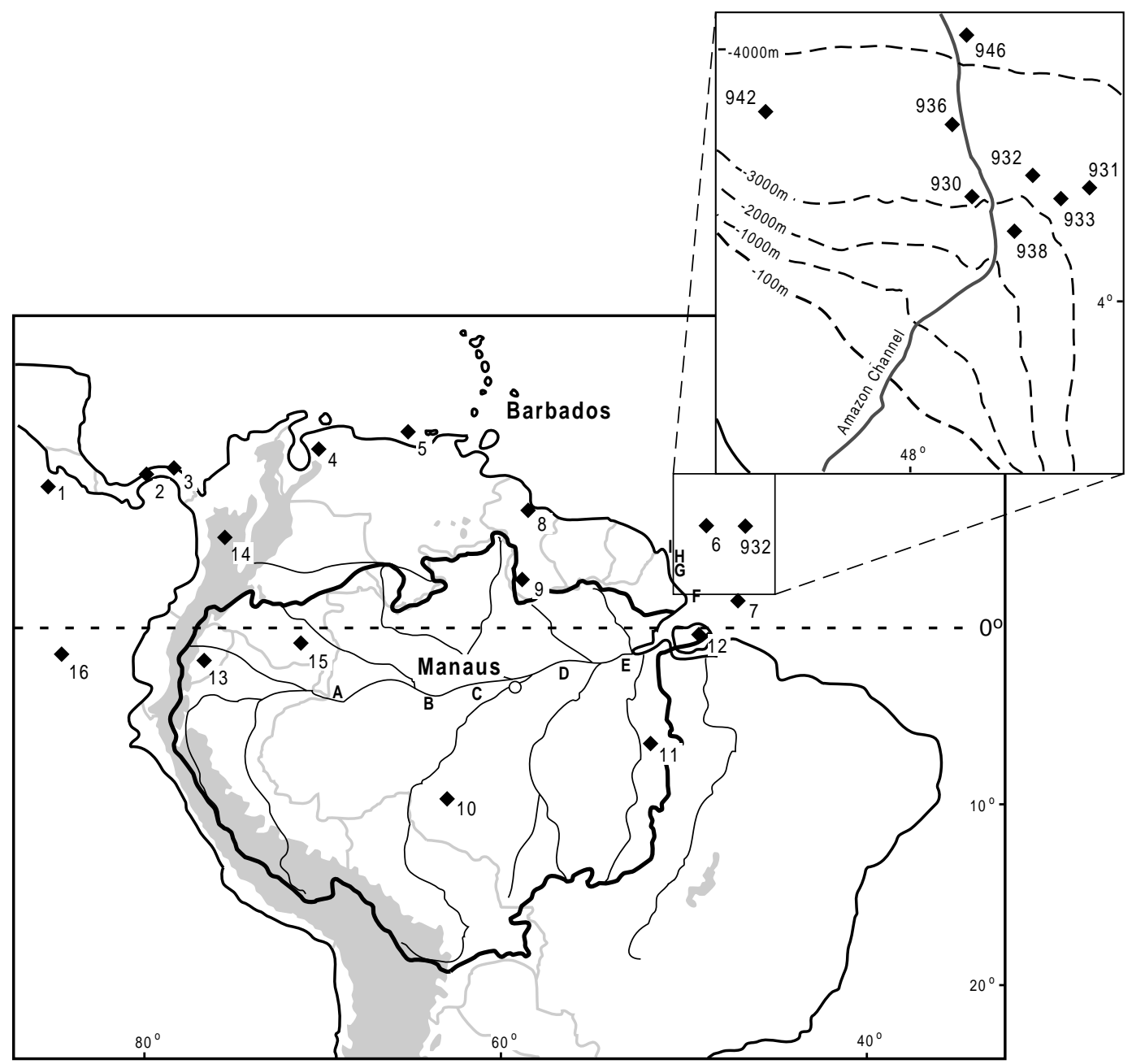

Figure 1. Map of sampling locations (A-H) within the Amazon River catchment area (heavy line) and the drilling sites on the Amazon Fan (inset box), with shading representing land $>2000 \mathrm{~m}$ altitude. Palaeoecological data mentioned in the text are numbered as follows: 1. DSDP site 565 (Horn, 1985); 2. El Valle (Bush and Colinvaux, 1990); 3. Gatun Basin (Bartlett and Barghoorn, 1973); 4. Lake Valencia (Leyden, 1985); 5. Cariaco Trench (Caratini et al., 1975); 6. Orgon II core KS12 (Caratini et al., 1975); 7. Orgon II core KS15 (Caratini et al., 1975); 8. Ogle Bridge (Van der Hammen, 1974); 9. Lake Moreiru (Van der Hammen, 1974); 10. Rondonia (Van der Hammen and Absy, 1994); 11. Serra dos Carajás (Absy et al., 1991); 12. Lake Arari (Absy, 1985); 13. Mera/San Juan Bosco (Bush et al., 1990); 14. Fuquene II (Van Geel and Van der Hammen, 1973) and Funza II (Hooghiemstra and Ran, 1994); 15. Caquetá River (Van der Hammen et al., 1992); 16. Tri 163-31B (Heusser and Shackleton, 1994).

the riverine systems and finally to deposition in submarine sediments is a critical first step in the interpretation of fossilized assemblages.

The modern vegetation of the Amazon River catchment area is remarkable in its species diversity and adaptation to different environments (Pires and Prance, 1985; Prance, 1987). The western edge of the catchment, defined by the Andes, is characterized by high-altitude grasslands between $3500 \mathrm{~m}$ and the snowline, grading down to montane forest $(>1000 \mathrm{~m})$. Species characteristic of the montane forest belt include Podocarpus, Weinmannia, Symplocos, Hedyosmum, and Alnus. At high altitude in the isolated mountains of the Guyana and Brazil Highlands, some of these cold-adapted taxa can also be found. Podocarpus may be found today as a rare element of lowland rain forest (Torres-Romero, 1988). The predominant lowland vegetation type is known as terre firme, a diverse evergreen closed-canopy forest, found on unflooded lands where there is a wet, generally aseasonal climate. In regions of increased seasonality, there are transition forests often dominated by semideciduous and palm communities that form a belt between terre firme and savanna vegetation. Extensive grasslands and savanna (variously referred to as cerrado sensu lato, caatinga, and Amazon savannas; Coutinho, 1990) occur to the north and south in areas of more seasonal climate and strong edaphic control. Floodplain vegetation (várzea and igapó) is found on the annually inundated parts of the central Amazon and is generally considered to be less diverse than the terre firme. Mangrove vegetation is extensive in the estuary of the Amazon River.

The history of Amazon Basin vegetation communities has been derived from palynological studies of swamp and lake sites, with much of the work focused on vegetation change in the Andes (Bush et al., 1990; Colinvaux et al., 1988; Hansen et al., 1984; Hooghiemstra and Ran, 1994; Salgado-Labouriau and Schubert, 1976; Van Geel and Van der Hammen, 1973; Van der Hammen and Gonzalez, 1960, 1965). Limited research has been carried out on riverine deposits and volcanic crater lakes found in the lowland Amazon Basin, with the most detailed records only spanning the last 6 k.y. (Absy, 1979, 1985; Lui and Colinvaux, 1988), and some longer Quaternary records (Absy et al., 1991; Colinvaux et al., 1996; Van der Hammen and Absy, 1994; Van der Hammen et al., 1992). Palynological aspects of the Amazon Fan previously have been investigated by Caratini et al. (1975), who showed that pollen and spore abundance was very poor in the calcareous-rich sediments associated with periods of 
high sea level, compared to the terrigenous mud-rich sediments associated with periods of low sea level. This relationship is confirmed by Leg 155 shipboard observations on organic matter distribution (Flood, Piper, Klaus, et al., 1995).

\section{METHODS}

Thirty-seven silty clay to clay samples from six sites (Sites 930, 931, 932, 936, 938, and 946) were collected for analysis during Leg 155. Core-catcher samples were collected to provide large sediment samples at regular depth intervals, and other samples at intermediate depths were collected to improve the resolution of sampling. These sites were thought to contain the most continuous sedimentary records for the last glacial period, although in all cases the postglacial and previous interglacial calcareous clays were found to be barren of pollen (Flood, Piper, Klaus, et al., 1995). Postglacial sedimentary environments were represented by four samples dating to within the last 5 k.y. from the continental shelf adjacent to the Amazon Fan and six suspended sediment samples from the Amazon River (Table 1; Fig. 1). These samples were included in the analysis to provide a comparison between the glacial Amazon Fan sediments and the postglacial Amazon River sedimentary environment.

Pollen extraction and analysis of all samples followed a modification of the standard fine-grained method (Heusser and Stock, 1984). Initially, 4- $\mathrm{cm}^{3}$ samples were dissaggregated overnight in sodium pyrophosphate $\left(\mathrm{Na}_{4} \mathrm{P}_{2} \mathrm{O}_{7} 10 \mathrm{H}_{2} \mathrm{O}\right)$ in a $10 \%$ solution with $\mathrm{H}_{2} \mathrm{O}$, then sieved through a $150-\mu \mathrm{m}$ mesh, and treated with $\mathrm{KOH}, \mathrm{HCl}, \mathrm{HF}$, and acetolysis solution. The $<150-\mu \mathrm{m}$ fraction was again dispersed in sodium pyrophosphate solution and sieved through a $7-\mu \mathrm{m}$ mesh to remove the abundant fine amorphous organics. The $>7-\mu \mathrm{m}$ samples were stained with Safarin O, mounted in glycerol oil, and counted taking a minimum pollen sum of 300 (excluding mangroves and reworked pollen types). In cases where pollen concentrations were very low, a minimum of 100 grains were counted. Pollen concentrations were calculated by adding Lycopodium clavatum tablets to samples before pollen extraction. The $<7 \mu \mathrm{m}$ fraction was also surveyed for possible "leakage" of small pollen types. Cecropia, Melastomataceae, Piperaceae, and diporate Moraceae pollen types were observed to pass through the fine mesh biasing the representation of these types in the fossil record. Counts of the "leakage" elements were included in the pollen sum by a simple fractional equation with known sample weight and concentration. Reworked pollen and spores were distinguished on the basis of guidelines set down by Stanley (1966) and included pre-Quaternary pollen and spores as well as all damaged and degraded types.

Pollen identification was assisted by regional reference collections held at the Smithsonian Tropical Research Institute and published pollen flora (Absy, 1979; Bartlett and Barghoorn, 1973; Cara- tini et al., 1975; Hooghiemstra, 1984; Hoorn, 1993; Roubik and Moreno, 1991). The pollen and spore taxa identified in this analysis are listed in Appendix Table 1 and are grouped according to broad habit and ecological characters. The pollen diagrams were prepared using TILIA and TILIAGRAPH programs (Grimm, 1988).

\section{TRANSPORT OF POLLEN AND SPORES TO THE AMAZON FAN}

A palynological survey of samples taken from the Amazon River and adjacent continental shelf (Table 1; Fig. 1) is incorporated into this study to investigate the nature of pollen and spore transport in a fluvial environment and to assess the potential of using pollen and spores brought down by the Amazon River to reconstruct past terrestrial environments. Traditionally, this information has been derived from land-based studies of pollen and spores from lakes and bogs. Bush (1991) shows from modern pollen deposition in lakes that it is possible to distinguish different tropical lowland vegetation types (e.g., the terre firme, semideciduous, floodplain forests, and savanna) in equatorial South America on the basis of associations of dominant pollen types. However, the same may not apply to river deposits because different processes are likely to be involved in the dispersal of pollen and spores in fluvial systems. Muller (1959) documented the importance of stream processes associated with the Orinoco River in delivering pollen and spores to the continental shelf of northern Venezuela. The vectors available for pollen and spores to reach the Amazon Fan include input from local riverbank vegetation, surface runoff, regional wind and rain, and a reworked component (primarily sediment erosion). Pollen and spores can also be blown offshore and contribute directly to the fossil assemblage found in marine sediments (cf. Horn, 1985; Heusser and Shackleton, 1994), although the prevailing south/northeasterly trade winds of the equatorial Atlantic would limit this contribution to the Amazon Fan.

Global climate has changed radically in the past altering both sealevel and ocean current circulation and, thus, the depositional pathway of pollen and spores to the Amazon Fan. Models of continental margin sedimentation suggest that during the Quaternary, at least three distinct patterns of sedimentation occurred on the Amazon Fan in response to sea-level changes (see Fig. 2; Gregory and Hart, 1992; Milliman et al., 1975). During high sea-level stands, river sediment does not escape the continental shelf environment due to the northeasterly flow of the North Brazil Coastal Current, limiting the terrigenous sediment input to the Amazon Fan (Nittrouer et al., 1995) and resulting in marine carbonate-rich mud deposition on the fan. Low sea-level stand sedimentation is characterized by relatively high terrigenous and low marine inputs that may exhibit cyclical rates of accumulation (Manley and Flood, 1988). Pollen and spores are very abundant during this phase with reworked palynomorphs in moderate

Table 1. Percentage representation (based on total pollen sum = arboreal + non-arboreal pollen, excluding mangroves and reworked pollen) of pollen and spores found in suspended sediments from the Amazon River and postglacial muds from the continental shelf (see Fig. 1 for locations).

\begin{tabular}{|c|c|c|c|c|c|c|c|c|c|c|c|c|}
\hline $\begin{array}{l}\text { Figure } 1 \\
\text { location }\end{array}$ & Sample & $\begin{array}{c}\text { Distance } \\
\text { from } \\
\text { Andes }(\mathrm{km})\end{array}$ & $\begin{array}{c}\text { Pollen } \\
\text { sum }\end{array}$ & Mangroves & Alnus & Podocarpus & Hedyosmum & Alchornea & Cecropia & Gramineae & Spores & $\begin{array}{c}\text { Reworked } \\
\text { pollen and } \\
\text { spores }\end{array}$ \\
\hline A & Vargem Grande $T_{0}$ & 1000 & 347 & 0 & 1.7 & 1 & 6.3 & 7.2 & 11 & 6 & 12 & 20 \\
\hline A & Vargem Grande $T_{f}$ & 1000 & 342 & 0 & 1 & 0 & 2.3 & 4.4 & 15 & 8 & 17 & 20 \\
\hline B & Tefe & 1700 & 359 & 0 & 1.3 & 0 & 5 & 1.3 & 41 & 7 & 10 & 5 \\
\hline $\mathrm{C}$ & Manaus & 2100 & 338 & 0 & 1.4 & + & 3.6 & 2.9 & 44 & 6 & 9 & 5 \\
\hline $\mathrm{D}$ & Santarem I & 2700 & 324 & 0 & + & + & 1.5 & 3.4 & 32 & 17 & 9 & 12 \\
\hline $\mathrm{E}$ & Santarem II & 3100 & 387 & 0 & 0 & 0 & 1.6 & 2.7 & 36 & 11 & 7 & 8 \\
\hline $\mathrm{F}$ & PC-4401 & 3700 & 319 & 2.2 & 0 & 0 & + & 2.6 & 30 & 9 & 6 & 8 \\
\hline G & PC-4218 & 3900 & 294 & 4.6 & + & 0 & + & 6.4 & 25 & 10 & 7 & 9 \\
\hline $\mathrm{H}$ & PC -4220 & 4000 & 335 & 5.3 & + & 0 & + & 3.1 & 38 & 6 & 6 & 15 \\
\hline I & PC-4216 & 4100 & 286 & 4.8 & 0 & 0 & 0 & 3.6 & 19 & 18 & 6 & 9 \\
\hline
\end{tabular}

Notes: Vargem Grande $=$ suspended particulate samples collected with a depth-integrated sampler by J. Hedges, School of Oceanography, University of Washington. PC $=$ collected and supplied by C. Sommerfield and C. Nittrouer, Marine Sciences Research Center, State University of New York, from AmasSeds piston core samples. $+=<1 \%$. 


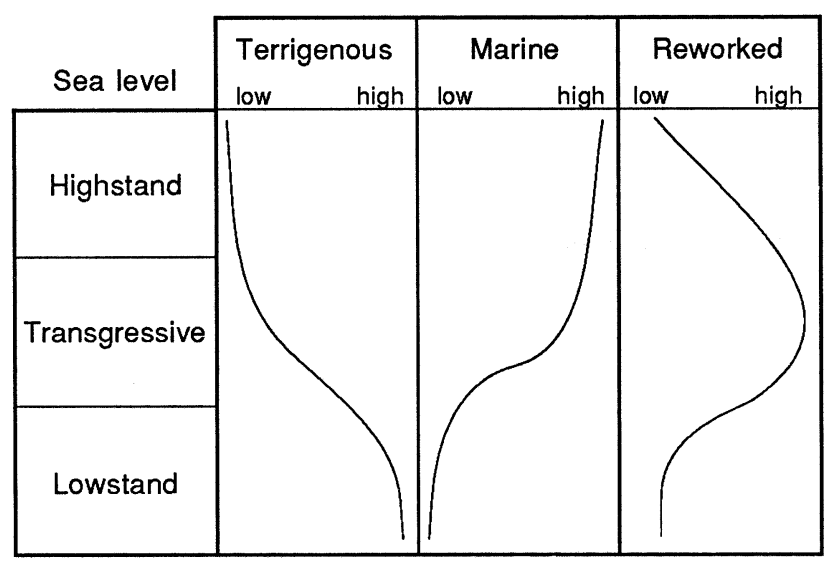

Figure 2. Idealized sequence for the Amazon Fan with model predicting relative amounts of terrigenous, marine, and reworked palynomorphs in response to sea-level change (adapted from fig. 14, Gregory and Hart, 1992).

abundance and marine palynomorphs low in abundance. The third sedimentation pattern involves relatively short-lived transgressive phases of sea-level change that are characterized by terrigenous dominance, high inputs of reworked palynomorphs, and a moderate input of marine palynomorphs. Peak freshwater discharge from Andean glacial meltwater has been suggested to occur during the sea-level rise phase of the late glacial $(13,500-6,000 \mathrm{BP}$; Showers and Bevis, 1988) and may be characterized by an increased reworked palynomorph component from soil erosion in the Andes mountains.

A summary of the pollen and spore assemblages found within the Amazon River and the continental shelf is given in Table 1 in order of increasing distance from the Andes. Some distinctive patterns of pollen abundance are evident: the pollen representation of montane arboreal taxa such as Alnus, Podocarpus, Hedyosmum and possibly most fern spores decrease with increasing distance from the high altitude Andean source; second growth arboreal taxa, including Didymopanax, Cecropia, Trema, and Gramineae are most abundant between Tefe and Santarem II, where present-day forest disturbance and savanna vegetation is concentrated (Pires and Prance, 1985); mangrove pollen are only found in continental shelf samples.

Many pollen types have very low representation and are only found as single grains in some samples. It is not clear if these types, some of which include Bombacaceae, Mauritia, Iriartea, Cordia, Symmeria, Byrsonima, and Croton, are good indicators of different vegetation types. The most abundant pollen types include Alchornea, Moraceae/Urticaceae, Melastomataceae/Combretaceae, Cecropia, and Palmae; however, with the exception of Cecropia, these do not show any clear trends in representation down the river. These same types have also been found to be abundant in terrestrial records (Bush, 1991), suggesting that one or a combination of factors including high pollen production, wind pollination, and abundance in many vegetation types contribute to their high representation in swamp and lake pollen assemblages as well as fluvial pollen assemblages. It is likely that a change in the extent of the source area vegetation, whether it be rain forest or savanna vegetation, would result in a change in percentage representation of associated pollen taxa in the fluvial assemblage, as is the case in bog and lake settings.

\section{CHRONOSTRATIGRAPHY OF AMAZON FAN SEDIMENTS}

The Cenozoic sediments of northern South America exhibit a series of palynological zonations based on the appearance and disappearance of fossil palynomorphs, correlated in time with planktonic microfossil zones (Germeraad et al., 1968; Lorente, 1986; Muller et al., 1987). The most recent of these, and the only zone referred to here, is found at the Tertiary/Quaternary boundary and is defined by the increased abundance of Alnipollenites verus (A. verus is the fossil form of the modern Alnus) which represents the establishment of North American temperate elements in South America. Alnus pollen were found in all the fan samples examined, indicating a maximum Quaternary age for sediment deposition. The addition of reworked pollen and spores, such as Grimsdalea magnaclavata (which is a biostratigraphic marker of middle to late Miocene sediments) to the fossil assemblage, presumably represents material derived from older pollen-bearing deposits eroding within the basin (Hoorn, this volume).

The age of each sample reported in Appendix Tables 2 and 3 was derived from four independent techniques: geomagnetic field excursions (Cisowski, this volume and 1995), AMS ${ }^{14} \mathrm{C}$ analysis (Flood et al., this volume), stable isotope analysis of planktonic foraminifers Globigerinoides ruber, G. trilobus, and Neogloboquadrina dutertrei (Maslin et al., this volume) and localized abundance datums for key planktonic foraminifers, such as the disappearance of Pulleniatina obliquiloculata between $\sim 40,000$ and 11,000 BP (Shipboard Scientific Party, 1995). All sample ages from Hole 932A are based on an age model derived from detailed $\delta^{18} \mathrm{O}$ records and geomagnetic field excursion data (Maslin et al., this volume). The base of Hole 932A at 170 meters below sea floor (mbsf) is assumed to be younger than $85,000 \mathrm{BP}$ due to the absence of G. tumida flexuosa, and this is assumed to represent a maximum age for this depth. Sample ages from other sites are derived by assuming constant sedimentation rates between the available key age datums (Table 2): base of lithostratigraphic Unit I containing postglacial crust $(\sim 10,000 \mathrm{BP})$, geomagnetic Lake Mungo Excursion ( 32,000 BP), P. obliquiloculata disappearance ( 40,000 BP), Laschamp Excursion ( 43,000 BP), and the Blake Event ( 105,000 BP).

\section{VEGETATION AND ENVIRONMENTAL RECONSTRUCTION}

Two approaches have been adopted in this study to reconstruct past vegetation from Amazon Fan fossil pollen assemblages. The first involves a comparison of samples from different sites across the fan that have similar sedimentary characteristics and pollen concentrations (Appendix Table 2). The analysis is designed to investigate the influence of spatial and temporal variables on the fossil pollen spectra and to establish a framework for interpreting changes observed in continuous high-resolution records. The second approach is to interpret a continuous pollen record that was constructed from samples from Holes 932A and 946A and that spans at least the last 105 k.y. (Appendix Table 3).

\section{Time Horizon and Species Analysis}

The pollen and spore percentage data from 15 samples, presented in Figure 3, illustrate the changes in taxonomic composition of fossil assemblages from different time periods and depositional environments. The samples have been selected from six sites on the fan and four sites on the continental shelf, and they are grouped into three time horizons: postglacial; LGM (15-18 ka); and Stage 3 (32-50 ka). There are some general patterns observed from the pollen and spore spectra, including an increase in Alnus, Podocarpus, Hedyosmum, and fern spores from the LGM to the postglacial and a decrease in second-growth arboreal pollen types including Cecropia, within the same time period. There appears to be little change in Gramineae and herb taxa throughout the record. The representation of reworked pollen and spores is variable.

The multivariate statistical analysis incorporated 48 pollen taxa that attained values of greater than $1 \%$ in at least one sample, with the exception of mangroves that were considered over-represented in the continental shelf samples and were not included in the pollen sum. Cluster analysis, multidimensional scaling analysis, species analysis, 
Table 2. Depth (mbsf) and occurrence of key geomagnetic and foraminifer age datums used at each site.

\begin{tabular}{cccccc}
\hline Site & $\begin{array}{c}\text { Postglacial } \\
\text { crust } \\
(10 \mathrm{ka})\end{array}$ & $\begin{array}{c}\text { Lake } \\
\text { Mungo } \\
(32 \mathrm{ka})\end{array}$ & $\begin{array}{c}\text { P. obliquiloculata } \\
(40 \mathrm{ka})\end{array}$ & $\begin{array}{c}\text { Laschamp } \\
(43 \mathrm{ka})\end{array}$ & $\begin{array}{c}\text { Blake } \\
(105 \mathrm{ka})\end{array}$ \\
\hline 930 & 0.55 & 85.2 & 137.0 & - & - \\
931 & 0.57 & 76.5 & - & - & - \\
932 & 0.70 & 25.9 & - & $\overline{-}$ & - \\
936 & 0.96 & $\overline{-}$ & -148.0 & - & - \\
938 & 0.44 & 146.0 & 149.0 & - & 134.0 \\
946 & 0.45 & 101.8 & - & - & \\
\hline
\end{tabular}

Note: $-=$ no data.

and analysis of similarity were carried out using the PRIMER (Clarke and Warwick, 1994) program. Cluster analysis allows a graphical display linking samples that have mutually high levels of similarity by grouping them into discrete clusters. The ordination technique, global nonmetric multidimensional scaling (MDS), gives a display of the interrelationships of groups on a continuous scale, and is considered one of the best techniques for analysis of taxonomic composition data (Clarke, 1993; Kenkel and Orlóci, 1986; Minchin, 1987). The ordination was constructed using the Bray-Curtis coefficient as a measure of compositional dissimilarity and then applying MDS in two dimensions (six random starts). Analysis of similarity (ANOSIM) was used to detect differences in pollen assemblages with respect to time and depositional environment, whereas a species analysis (SIMPER) identifies species that contribute the most to dissimilarity between different groups.

Figure 4 displays the cluster analysis and two dimensional MDS scores for the 15 pollen samples. The four postglacial samples from the continental shelf appear to display the greatest internal similarity and are separated from the other samples in both the cluster and MDS analysis (Fig. 4A, B). The null hypothesis, that samples from different time horizons cannot be distinguished on the basis of pollen spectra, was tested using a global and pairwise significance test (ANOSIM) whose results are displayed in Figure 4C. The global $R$ test gives a positive $R$ value of $0.40(p<0.01)$, suggesting that the null hypothesis can be rejected. The pairwise test shows that the most significant separation occurs between the postglacial samples and the LGM samples, with a positive $R$ value of $0.80(p<0.01)$. This result may be explained in terms of vegetation change within the basin or simply the different depositional environments from which the samples are derived: shelf deposits and deep sea fan deposits. The analysis of more samples from the continental shelf may help to clarify this problem, although it is noteworthy that all samples used in this analysis have similar pollen and spore concentrations (Appendix Table 2): a variable that may be expected to show markedly different values if influenced by sorting or preservational biases related to depositional dynamics. The lack of distinction between the LGM and Stage 3 (32-50 ka) samples does not help the interpretation as the global climatic variability present within the latter broad time period is high.

A breakdown of the contributions made by individual taxa to the dissimilarity between the postglacial and LGM sample groups is given in Table 3. Taxa likely to be good discriminators between these two sets of samples are marked with an asterisk, although it can be seen that many in this partial list play some part in determining this dissimilarity. The most discriminating taxa include, Alnus, Cecropia, Hedyosmum, Melastomataceae/Combretaceae, Moraceae/Urticaceae, Myrtaceae, and Symmeria. From group B (LGM fan) to group A (postglacial shelf), Alnus, Hedyosmum, Melastomataceae/Combretaceae, Moraceae/Urticaceae, and Myrtaceae show decreased percentage representations and Cecropia and Symmeria show increased percentage representations.

The explanation for this selection, as suggested above, may simply lie in the different sedimentation processes on the shelf as compared with the fan. However, the contradictory percentage trends in taxa of similar grain size and shape, such as Cecropia and Moraceae/
Urticaceae, suggest that there is no sorting bias toward a particular pollen grain size. The similarity between the pollen concentration values from the shelf and fan deposits (see Appendix Table 2) also suggests that sediment sorting processes have not contributed to changing pollen assemblage characteristics. The alternative explanation is that the expanding and contracting distribution of plant species within the basin is reflected in the changing percentage representation of fossil pollen and spore taxa. The implications of percentage shifts in the most discriminating taxa from the LGM to postglacial will be discussed in the light of the continuous record from Holes 932A and 946A.

\section{Continuous Pollen and Spore Record}

The pollen and spore analysis from two holes on the Amazon Fan, Hole 932A and Hole 946A, are presented together in two diagrams. Postglacial samples from the continental shelf are also presented for comparison. The first diagram (Fig. 5) includes a summary of the ratios of major pollen groups included within the total pollen sum: pteridophyte spores, reworked pollen and spores, estimates of the concentration of identifiable non-reworked pollen, and relative percentage of dynoflagellate cysts and microforaminifers. Two indices have been constructed to show the changes in known taxa groupings relative to the total arboreal taxa (see Appendix Table 1). The ColdAdapted Vegetation Index (CAV Index) represents the ratio between the sum of cold-adapted arboreal taxa, such as Alnus, Hedyosmum, Podocarpus, and Symplocos, and total arboreal pollen sum. The "Disturbance Index" represents the ratio between the sum of second growth taxa, such as Acalypha, Cecropia, Didymopanax, and Trema, and total arboreal pollen sum. The second diagram (Fig. 6) shows the percentage values of selected identified pollen and spore taxa.

Pollen is moderately abundant in sediment from Holes 932A and 946A, with concentrations ranging from 2000 to 40,000 pollen grains $/ \mathrm{cm}^{3}$ of sediment (Appendix Table 3). Palynomorph preservation ranges from good to poor within each sample, with spores especially showing signs of bacterial or fungal attack. Older reworked palynomorphs (e.g., Grimsdalea magnaclavata, a biostratigraphic marker of Miocene to Pliocene sediments) are found in a number of samples, highlighting the complex mixing of palynomorphs that can be encountered in fluvial deposits. The composition of the fossil pollen and spore assemblages changed little through much of the recorded period although, the relative contributions from individual taxa fluctuate continually. Arboreal taxa dominate, with substantial contributions from taxa such as Melastomataceae/Combretaceae, Moraceae/Urticaceae, Cecropia, Serjania, Myrtaceae, and Alchornea. Many other arboreal taxa are represented in very low percentages and only appear infrequently throughout the sequence. The grasses and other non-arboreal taxa generally associated with open vegetation environments, including savanna, exhibit only minor fluctuations throughout and represent up to $25 \%$ of the total pollen sum.

The major changes within the sequence are shown by the general increase in representation of Alnus, Hedyosmum, Podocarpus, and other cold-adapted taxa in the glacial. Figure 5 illustrates the peak values in the Cold-Adapted Vegetation Index curve between 17,000 and 21,000 BP (8.01 and $11.2 \mathrm{mbsf})$ at a time when the climate was cooler than present. The expansion of Podocarpus, typically found in cool moist forests today, is particularly marked at the LGM at this hole. Hedyosmum, a cold-adapted heliophytic taxa, peaks just before Alnus and Podocarpus at 21,000 BP. Alnus and Hedyosmum show this same relatively high percentage representation from LGM samples across the fan that is consistent with the climatic forcing explanation suggested in the previous section. A general increase in pteridophyte spores, whose parent plants are abundant in cooler forests, supports this interpretation of a general expansion of cold-adapted forest taxa at the LGM.

A second peak in the Cold-Adapted Vegetation Index occurs at the base of the Hole 946A record before 105,000 BP and is characterized by high representation of Alnus and Hedyosmum, although 


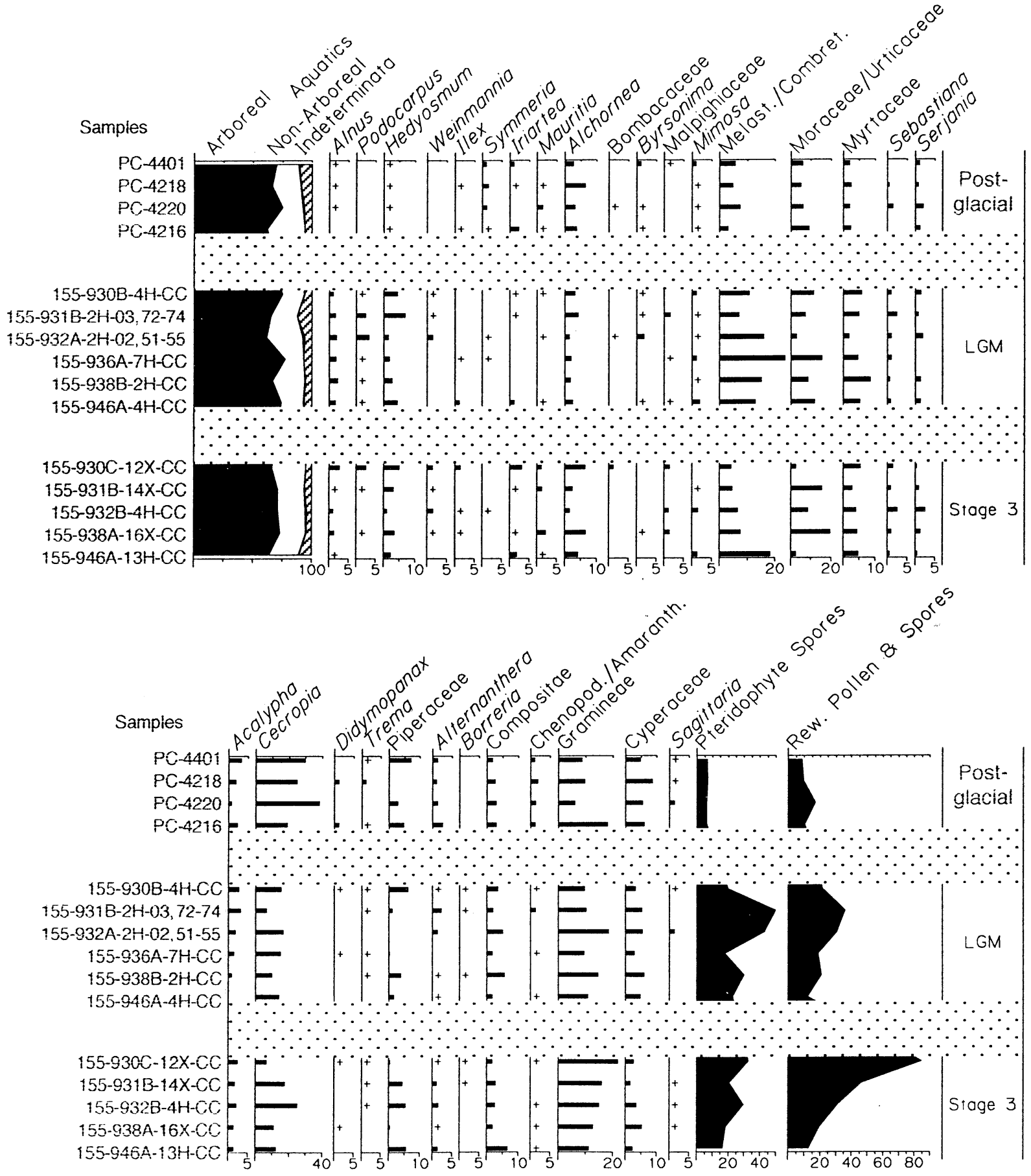

Figure 3. Summary diagram of fossil pollen, spores, and marine microfossils from postglacial continental shelf deposits and glacial Amazon Fan Sites 930, 931, 932, 936, 938, and 946 (percentages based on total pollen sum = arboreal + non-arboreal pollen, excluding mangroves and reworked pollen). Horizontal stippled bar represents a break in the record. $+=<1 \%$.

Podocarpus is not as common in this earlier period. Between these peaks in cold-adapted taxa, slightly lower Cold-Adapted Vegetation Index values are maintained, although there is a continually fluctuating representation in most other arboreal taxa. Between 28,000 and 36,000 BP (19.9 and $25.7 \mathrm{mbsf}$ ) in Hole 932A and at 33,000 BP (117.4 mbsf) in Hole 946A, a minimum for the Cold-Adapted Vegetation Index is reached that is comparable to postglacial values. Peaks in the abundance of marine microfossils (dinoflagellate cysts and microforaminifers) and reworked pollen and spores appear just after peaks in the Cold-Adapted Vegetation Index (excluding the postglacial samples), possibly in response to the erosive consequences of the transgressive phase in sea-level change.

The record of Gramineae and other non-arboreal taxa exhibit a remarkable stability relative to the changes seen in the arboreal taxa. Gramineae includes species adapted to a wide range of habitats, including savanna (C4 grasses; Chloridoid and Panicoid) and rain forest understorey (C3 grasses; Bambusoideae), although the pollen morphology of Gramineae does not allow for savanna taxa to be iden- 
(A)

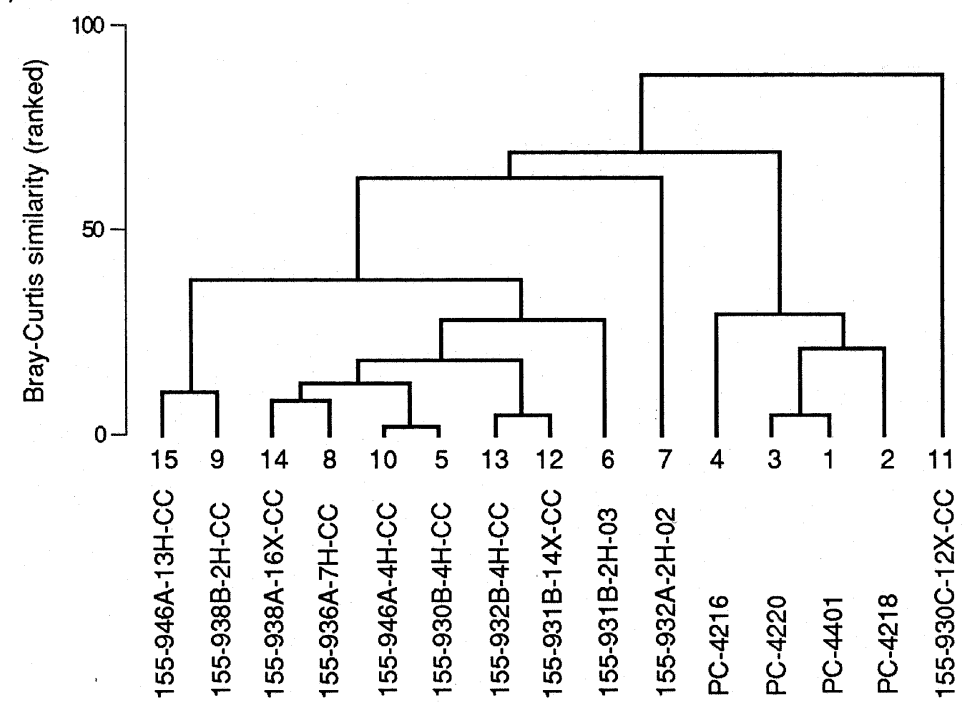

(B)

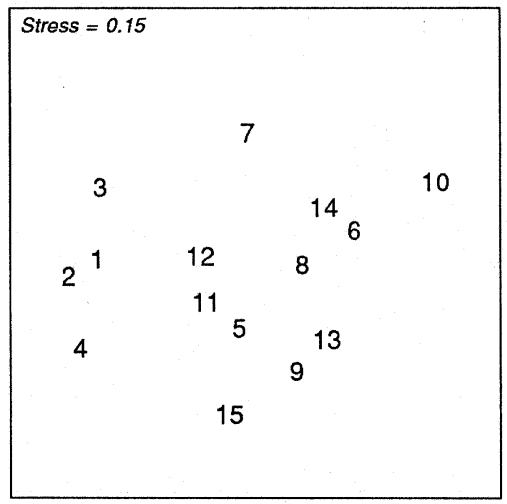

(C)

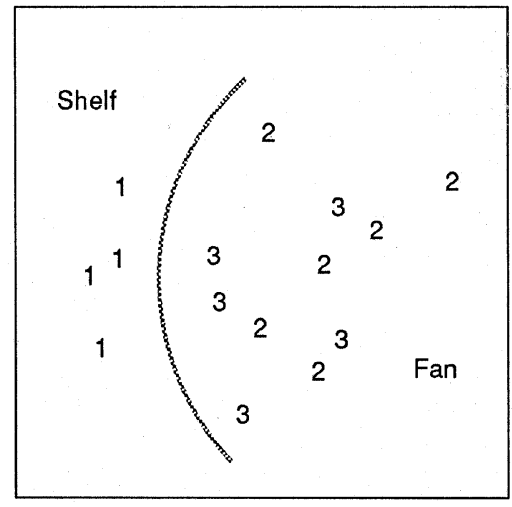

Figure 4. A. Dendrogram for hierarchical clustering of the 15 samples listed in Appendix Table 2, using group-average linking. B. MDS ordination of BrayCurtis similarities from $\sqrt{ }$-transformed pollen percentage data for the sites listed in Appendix Table 2. C. The same MDS but with samples identified as time horizons grouped by letter (see text).
Table 3. Similarity breakdown of Amazon Fan and Continental Shelf pollen.

\begin{tabular}{|c|c|c|c|c|c|}
\hline Taxon & $\begin{array}{l}\text { Group A: } \\
\text { postglacial } \\
\text { average } \\
\text { abundance } \\
(\%)\end{array}$ & $\begin{array}{c}\text { Group B: } \\
\text { last glacial } \\
\text { maximum } \\
\text { average } \\
\text { abundance } \\
(\%)\end{array}$ & $\delta_{\mathrm{i}}$ & Ratio & $\begin{array}{l}\sum \delta_{i} \\
(\%)\end{array}$ \\
\hline Hedyosmum & 0.0 & 3.5 & 2.2 & $8.7 *$ & 6.6 \\
\hline Alnus & 0.0 & 1.6 & 1.9 & $13.1 *$ & 12.2 \\
\hline Symmeria & 1.0 & 0.1 & 1.2 & $2.0 *$ & 15.9 \\
\hline Piperaceae & 3.7 & 2.2 & 1.1 & 1.2 & 19.2 \\
\hline Iriartea & 0.8 & 0.2 & 0.9 & 1.0 & 30.6 \\
\hline Didymopanax & 0.6 & 0.1 & 0.9 & 1.1 & 38.7 \\
\hline Chenopod./Amaranth. & 1.3 & 0.4 & 0.8 & 1.2 & 43.8 \\
\hline Byrsonima & 0.5 & 0.6 & 0.8 & 1.1 & 53.2 \\
\hline Trema & 0.6 & 0.3 & 0.7 & 1.1 & 55.4 \\
\hline Melast./Combret. & 5.0 & 14.0 & 0.7 & $1.9 *$ & 57.6 \\
\hline Podocarpus & 0.0 & 0.9 & 0.7 & 0.7 & 66.2 \\
\hline Cecropia & 27.7 & 12.8 & 0.7 & $2.0 *$ & 13.6 \\
\hline Myrtaceae & 2.1 & 5.1 & 0.5 & $2.1 *$ & 82.2 \\
\hline Moraceae/Urticaceae & 3.9 & 7.3 & 0.5 & $1.8^{*}$ & 85.0 \\
\hline Alchornea & 4.0 & 2.4 & 0.3 & $\begin{array}{l}1.0 \\
1.3\end{array}$ & $\begin{array}{l}0.0 \\
94.9\end{array}$ \\
\hline Gramineae & 10.6 & 12.1 & 0.3 & 1.3 & 96.9 \\
\hline Ilex & 0.0 & 0.2 & 0.3 & 0.49 & 7.7 \\
\hline Compositae & 3.2 & 2.5 & 0.2 & 1.4 & 98.5 \\
\hline
\end{tabular}

Notes: Breakdown of average dissimilarity between groups A (postglacial) and B (last glacial maximum) into relative significance of the contribution from each taxon; selected taxa are ordered in decreasing contribution. Total average dissimilarity (A and B) $\sum \delta_{\mathrm{i}}=33$. $*$ species likely to be good discriminators of groups $\mathrm{A}$ and $\mathrm{B}$. tified. Minor increases in other taxa that may be associated with savanna environments, such as Croton and Borreria, appear only during the glacial period. In addition, Byrsonima increases slightly from 21,000 to $17,000 \mathrm{BP}$, raising the possibility of an increase in open vegetation environments in response to drier conditions in parts of the Amazon Basin. The pollen spectra suggest that savanna communities persisted during the glacial period and may have expanded, particularly in areas of poorer soils and lower precipitation, although the percentage changes in pollen taxa are less significant than those associated with the cold-adapted taxa.

The Disturbance Index curve in Figure 5 emphasizes the fluctuating representation of second growth taxa within the glacial forest community. Cecropia is the most abundant of the second-growth taxa and shows a general increase in representation from LGM to postglacial across the fan. The marked difference between postglacial and glacial values for this index may represent a change in the relative community turnover time from long-lived communities and low occurrence of second-growth taxa in the glacial periods compared with shorter community turnover time and higher occurrence of second growth taxa in the postglacial period. This change may be driven by different climatic conditions, an increase in active river migration in the postglacial, or the influence of human activity in the postglacial.

Mangroves were present during the glacial period, but the low percentages relative to the postglacial suggest that coastal communities were probably restricted to a narrow coastal strip as the continental shelf steepens below the $-80 \mathrm{~m}$ contour. Mauritia, Cyperaceae, 


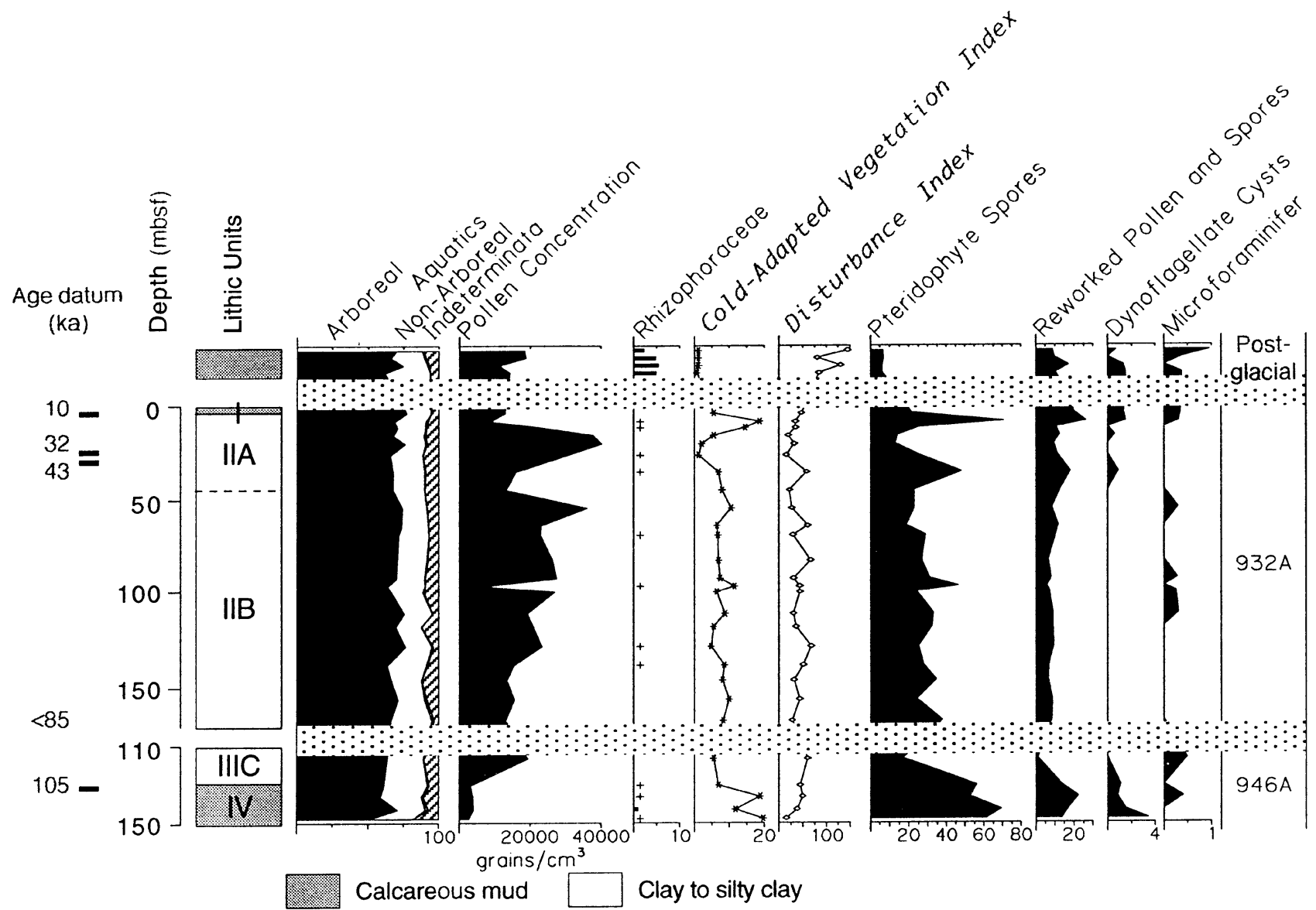

Figure 5. Summary diagram of fossil pollen, spores, and marine microfossils from postglacial continental shelf deposits, Holes 932A and 946A (percentages based on total pollen sum $=$ arboreal + non-arboreal pollen, excluding mangroves and reworked pollen; see text for explanation of indices). Horizontal stippled bar represents a break in the record. $+=<1 \%$.

and Sagittaria maintain low percentage representation during the glacial record, suggesting that lowland wetland environments persisted. However, the marked reduction in percentages of Symmeria during the glacial points to a restricted distribution of inundated forest relative to the postglacial. The lower sea level and deeper Amazon River channel may have been sufficient to reduce the area of periodically inundated land, probably restricting várzea and igapó type vegetation to the western margins of the Amazon Basin.

\section{REGIONAL COMPARISONS}

The changes in the composition of pollen assemblages derived from river sediments deposited off the mouth of the Amazon River during the last glacial belong to low and transgressive sea-level phases and are considered to show changes in the composition and distribution of lowland and upland plant communities of the Amazon Basin during this time. A summary of the major vegetation changes and climatic interpretation from selected sites in the Amazon Basin region is presented in Figure 7. The diagram sets out to illustrate the comparative aspects of paleoecological data sets from sites in the high altitude Andes, lowland Amazonian, and coastal regions.

Oxygen isotope variations in the SPECMAP data set (Martinson et al., 1987) and proxy estimates of temperature change in the Colombian Andes (Hooghiemstra and Ran, 1994; Van Geel and Van der Hammen, 1973) are plotted in Figure 7 against selected pollen and spore taxa curves from Holes 932A and 946A and arboreal pollen percentages from Colombia (Funza II and Fuquene II), Ecuador (Tri
163-31B) and the Amazonian lowlands (Serra dos Carajás). Arboreal and Gramineae pollen percentages from the Amazon Fan record do not clearly follow the changes in global climate (temperature record), although slightly reduced arboreal percentages during the LGM may relate to reduced forest cover. The best correspondence between the Amazon Fan and terrestrial records appears to be with the changes in cold-adapted taxa.

Peak abundances in the Cold-Adapted Vegetation Index from the Amazon Fan record correspond to low percentages in arboreal taxa recorded in the Colombian and Ecuadorian Andes at the LGM, at a time when treelines were lowered to $\sim 2000 \mathrm{~m}$ altitude in response to a cooling of up to $7^{\circ} \mathrm{C}$ (Van der Hammen, 1974). Cold-adapted forest taxa appear to have had an expanded distribution downslope during the glacial period. The peak percentages of Hedyosmum just prior to peak Alnus and Podocarpus percentages suggest that high Andean forests became less continuous before the LGM possibly due to increased forest disturbance from localized cold-air drainage. A second major cold peak in the Cold-Adapted Vegetation Index at the base of Hole 946A record is poorly time constrained, but it may correspond to Stage 6 glacial maximum or cold Substage 5.4, represented by low arboreal percentages in the Funza II record. The warm Cold-Adapted Vegetation Index between 28,000 and 36,000 BP corresponds to a greater representation of arboreal taxa toward the base of the Fuquene II and toward the top of Funza II record and is coincident with higher lake levels. A similar correspondence is found with the Mera/San Juan Bosco sequences where warmer temperatures appear to persist for at least 4 k.y. after 30,000 BP (Bush et al., 1990). The step-like changes in representation of cold-adapted taxa point to the possible 

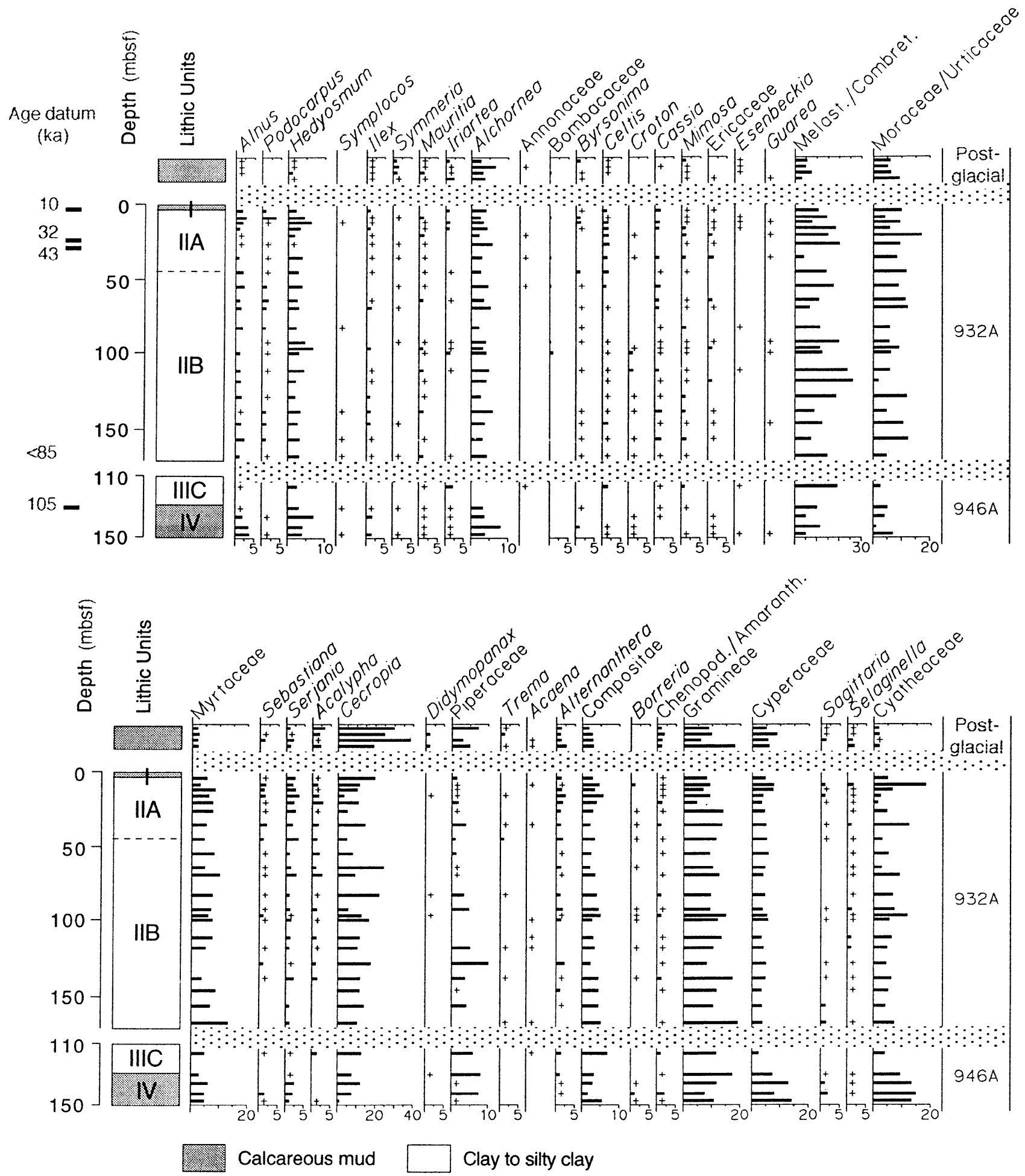

Figure 6. Diagram of pollen and spore taxa identified from postglacial continental shelf samples, Holes 932A and 946A (percentages based on total pollen sum $=$ arboreal + non-arboreal pollen, excluding mangroves and reworked pollen). Horizontal stippled bar represents a break in the record. $+=<1 \%$.

incorporation of these taxa in the vast lowland environment during cold glacial phases and a restriction of these same taxa to the limited extent of the Andes during warmer periods.

That the lowland Amazon Basin was also subject to a reduction in temperature of between $5^{\circ} \mathrm{C}$ and $7.5^{\circ} \mathrm{C}$ during glacial periods, providing conditions suitable for the incorporation of cold-adapted taxa into lowland forest communities, has recently received support from a range of independent sources. The Mera/San Juan Bosco sequences at $\sim 1000 \mathrm{~m}$ altitude suggest that during oxygen isotope Stage 3 the lowlands experienced cooling of up to $7.5^{\circ} \mathrm{C}$, between 33,000 and 30,000 BP (Bush et al., 1990). Bush and Colinvaux (1990) have shown that the tropical lowlands of Panama (El Valle) held rain forest 


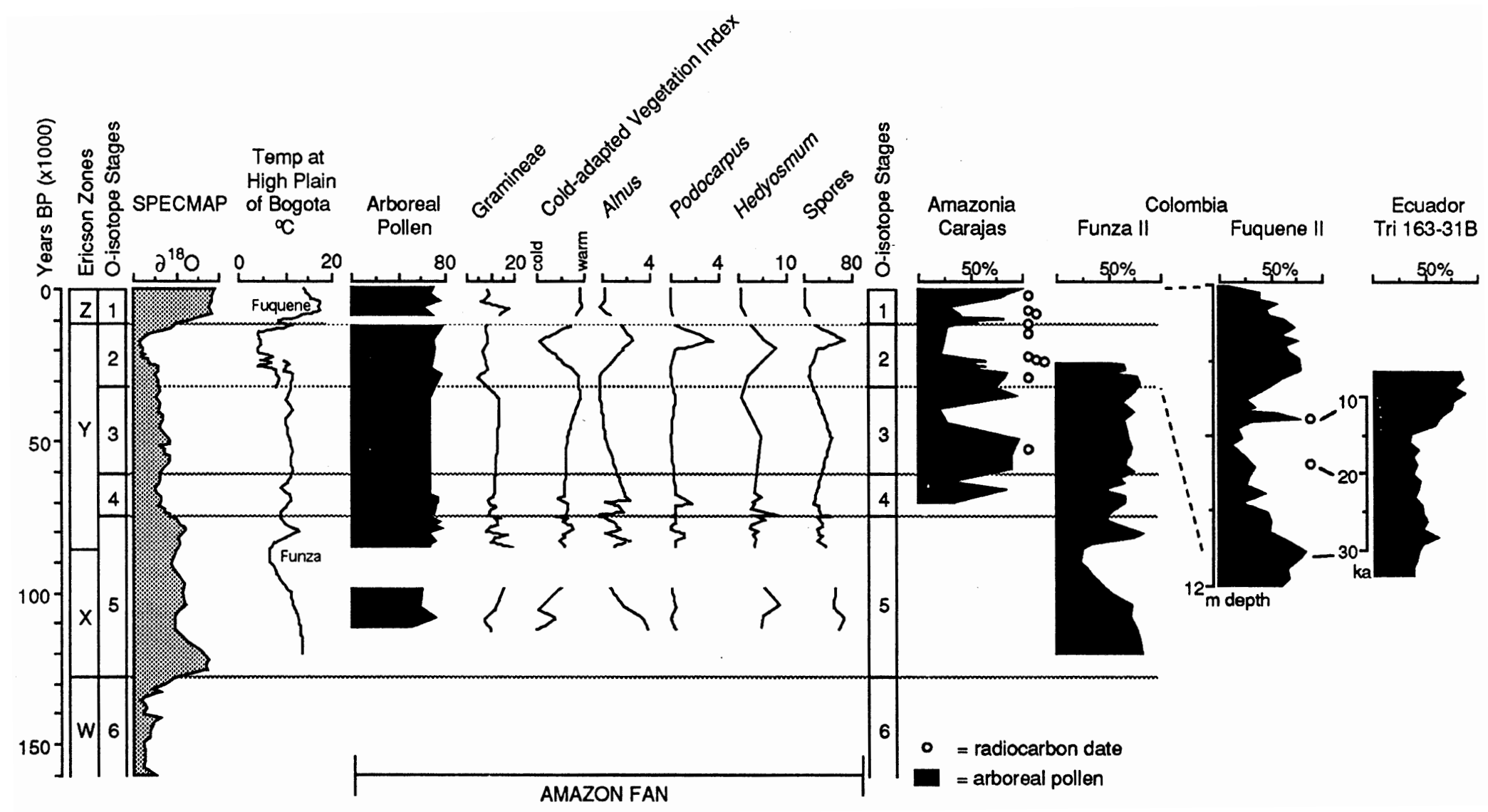

Figure 7. Correlation of the Ericson Zones and SPECMAP oxygen isotope record with Hole 932A/946A selected pollen record (inverted Cold-adapted Vegetation Index), arboreal pollen percentages from Colombia (Fuquene II, adapted from Van Geel and Van der Hammen, 1973; Funza II adapted from Hooghiemstra and Ran, 1994), Ecuador (Tri 163-31B, adapted from Heusser and Shackleton, 1994), and lowland Amazonia (Serra dos Carajás, Lake 8, adapted from Absy et al., 1991). Ages of terrestrial pollen sequences have been estimated using tentative correlation with oxygen isotope stratigraphy and ${ }^{14} \mathrm{C}$ dates where available. 
during the glacial period and experienced at least a $5^{\circ} \mathrm{C}$ cooling at the LGM. Guilderson et al. (1994) suggest that sea-surface temperatures off Barbados were cooler during the LGM than predicted by CLIMAP, and groundwater temperature estimates in central Brazil (Stute et al., 1995) lend further support to a $5^{\circ} \mathrm{C}$ cooling for the LGM equatorial lowlands. An expansion of cold-adapted taxa downslope in the Andes and into the lowland basin in response to significantly cooler glacial temperatures has been suggested by studies from lowland terrestrial sites (Colinvaux et al., 1996) and is consistent with these changes in fan pollen assemblage.

Periodic expansion of savanna vegetation in the lowlands of the Amazon Basin is recorded at a number of sites, located within savanna regions today or within transition forest areas, and appears to correspond in time with the cold-dry LGM environment of the uplands (Caquetá River; Van der Hammen et al., 1992; Rondonia and Serra dos Carajás; Van der Hammen and Absy, 1994). However, it is not yet clear from terrestrial pollen evidence the extent of savanna expansion within the basin during the glacial period. The phytolith record of Piperno (this volume) shows an increase in the $\mathrm{C} 4$ grasses at the LGM, which is interpreted as an expansion of savanna environments. Under the influence of lower atmospheric $\mathrm{CO}_{2}$ levels (Bird et al., 1992; Bush, 1994), the C4 grasses would have had a competitive advantage over C3 plants at the LGM, forcing a shift in species dominance within existing savanna communities and possibly an expansion of savanna environments, contributing to the rise in $\mathrm{C} 4$ grass phytoliths. It is clear, however, that periods of lower temperature and atmospheric $\mathrm{CO}_{2}$ are not exclusively accompanied by dry conditions, as savanna vegetation is seen to develop during the postglacial in some areas (e.g., Lake Arari; Absy, 1985). Earlier episodes of savanna expansion in the Serra dos Carajás record may correspond to cold periods recorded in the Andes, although, as with all the correlations prior to $\sim 30,000 \mathrm{BP}$, the poor reliability of ${ }^{14} \mathrm{C}$ dating due to contamination makes direct correlation difficult. This difficulty is exacerbated in the Rondonia and Caquetá River sites where low sample resolution and possible contamination of the ${ }^{14} \mathrm{C}$ dates in river terrace deposits (Räsänen et al., 1991) are problematic factors.

Pollen records from marine sediments taken from the Cariaco Trench off northern South America show well-preserved pollen interpreted to be derived from the forest, savanna, and mangrove vegetation of northern Venezuela that reflect vegetation changes forced by fluctuations in climate and sea level (Caratini et al., 1975). These records can be correlated with terrestrial sequences from Guyana (Wijmstra and Van der Hammen, 1966; Van der Hammen, 1963) and Venezuela (Leyden, 1985) to show that savanna was an important vegetation type in the northern coastal region of South America toward the end of the glacial, and that mangroves expanded along the coast in response to a rising sea level during the transition from glacial to postglacial conditions (Tissot et al., 1988). In contrast, marine records from Deep Sea Drilling Project (DSDP) Site 565 located off the coast of western Costa Rica (Horn, 1985), and the Amazon Fan pollen records, including three piston cores (core KS12, KS15, and KS17) surveyed by Caratini et al. (1975), show very little variation in pollen from savanna vegetation taxa in the glacial sediments. It appears that the dramatic changes in savanna vegetation recorded along the north coast of South America were not replicated in the Amazon Basin or western parts of Central America. An equatorward shift of mid-latitude cloud cover, as suggested by Guilderson et al. (1994), and a southern shift of the ITCZ may have been sufficient factors to mitigate moisture loss from lower sea-surface temperatures across parts of the Amazon Basin.

The low representation of disturbance elements in the glacial periods relative to the postglacial may be interpreted in a number of ways. First, the changing hydrodynamics of the Amazon Basin with lower sea level may have reduced the occurrence of riverine disturbance (Salo et al., 1986) during glacial periods, with the Amazon
River laterally restricted to a deep channel particularly in the eastern sector of the basin (Irion, 1984). The lack of Quaternary age floodplain lake sediments in the Amazon (Räsänen et al., 1991) attests to the influence of a deeper Amazon River channel resulting in reduced overbank flooding and restricted flooded forest environments. Second, the longevity of lowland forests may have changed in the past under the influence of altered climatic conditions as well as fluvial conditions. The postglacial disturbance maximum may be explained by a decrease in the mean age of the major forest species relative to the glacial forest due to a more rapid turnover of the lowland forest taxa. Lowland angiosperms may have a mean lifespan of 200-300 yr, in contrast to gymnosperms, such as Podocarpus, which may live 500-700 yr (Hope and Tulip, 1994). Third, the changes in disturbance levels may be linked to anthropogenic influences on the vegetation that are believed to have been initiated in the Americas as early as 11,000 BP (Lake La Yeguada; Piperno et al., 1990) and may have been extensive in the Amazon Basin by 6000 BP (Meggers, 1984; Roosevelt, 1991). This is consistent with the 12,000-14,000 BP occupation hypothesis for the Americas (cf. Hoffecker et al., 1993; Lynch, 1990), but does not rule out a more passive human occupation of the region at an earlier stage in the upper Quaternary (cf. Dillehay, 1989; Guidon and Delibrias, 1986). A detailed fire-history from the investigation of carbonized particles from Amazon Fan sediments, as well as terrestrial paleoecological sites, will help shed new light on this problem (Piperno, this volume).

\section{Lowland Forest Fragmentation During the Glacial}

The most widely accepted explanation for the great floral and faunal species diversity seen in the Amazon Basin is based on the notion that the lowland forest fragmented into isolated refugia during the glacial episodes of the Quaternary (Brown, 1987; Haffer, 1969; Prance, 1987) resulting in centers of evolutionary divergence for forest species. The limited paleoecological data from the lowlands of the Amazon Basin (supported primarily by the Caquetá River, Rondonia, and Serra dos Carajás sites) have been interpreted to suggest severe aridity in the lowland tropics at the LGM resulting in widespread expansion of savanna and fragmentation of rain forest. Colinvaux (1987) and Salo (1987) reviewed the shortcomings of the paleoecological and geomorphological data presented to support the refugial hypothesis and found no unequivocal evidence of widespread glacial age aridity. Bush (1994) has further suggested that widespread forest fragmentation is not essential to Quaternary speciation. A more complex evolutionary model should be proposed, however, where centers of forest endemism are the result of repeated species assortment under the influence of climatic disruption. This disruption includes moderate non-uniform reductions in precipitation as well as substantial cooling and reduced atmospheric $\mathrm{CO}_{2}$.

How extensive was forest fragmentation, if at all, during the LGM? Figure 8 illustrates modern vegetation and two alternative estimates of the extent of savanna vegetation during the LGM with an addition of exposed continental shelf along the north and east coast. Model 1 is based on a uniform reduction in precipitation of $20 \%-$ 25\% (after maps drawn by Bush, 1994; Van der Hammen and Absy, 1994) with forest growing on the exposed continental shelf, resulting in $\sim 32 \%$ savanna cover within the catchment area. Model 2 is based on predictions of the distribution of rain forest refugia with precipitation reduced by at least $40 \%$ (after maps drawn by Brown, 1987; Van der Hammen and Absy, 1994), resulting in $80 \%$ savanna cover within the catchment area. If the Amazon Fan pollen record from the LGM (non-arboreal $<25 \%$, minimal changes in Gramineae, Compositae, and Byrsonima) is compared with the model estimations of percentage area of savanna within the Amazon catchment, then Model 1 appears to be more consistent with the pollen record. 
Figure 8. Sketch map of modern vegetation and LGM vegetation within the catchment of the Amazon River predicted to carry alpine (dark), rain forest (medium), and savanna (light) vegetation. Model 1: LGM vegetation under a $20 \%-25 \%$ reduction of precipitation and rain forest on exposed continental shelf (model and maps adapted from Bush, 1994; Van der Hammen and Absy, 1994). Model 2: LGM vegetation under at least $40 \%$ reduction of precipitation and with savanna on exposed continental shelf (model and maps adapted from Brown 1987; Van der Hammen and Absy, 1994).
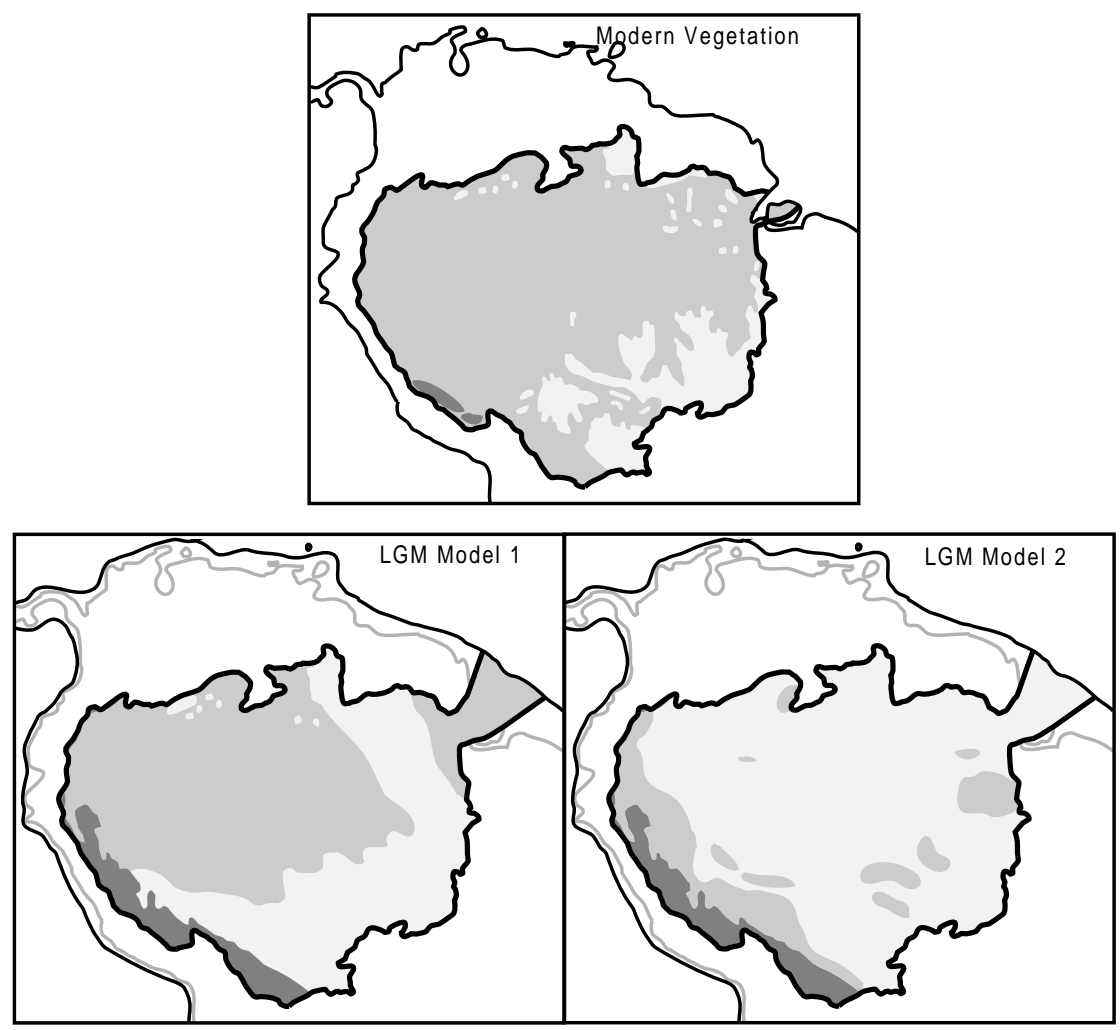

\section{CONCLUSIONS}

Pollen analysis of samples from the Amazon Fan show changes in pollen frequencies that may reflect vegetational changes in the Amazon Basin through at least the last 105 k.y. A striking feature of the continuous pollen diagram constructed from Holes 932A and 946A, is the increase in cold-adapted taxa during the LGM. The glacial Amazon forests appear to have been characterized by continual resorting of composition and structure through time that involved the incorporation of cold-adapted taxa, now separated by temperature and altitude (e.g., Podocarpus), into novel lowland communities. The accumulating pollen and phytolith evidence from the Amazon Basin strongly suggests only moderate expansion of savanna at the expense of rain forest at the LGM and points to the need for other factors. These include temperature and atmospheric $\mathrm{CO}_{2}$, to be incorporated as an important controlling factor for historical plant distribution in the lowland Amazon Basin as well as in the Andes.

In order to advance our knowledge of the environmental history of this region future additions to the paleoecological database for the Amazon Basin should include: (1) detailed and well-constrained chronologies to enable inter-site correlations; (2) higher resolution sampling of at least millennium scale to resolve broad climatic cycles (Milankovitch cycles) and limit ambiguity in interpretations; and (3) a consideration of the range of complex climatic and anthropogenic factors influencing vegetation patterns. Until these basic guidelines are followed, the assumption that widespread aridity is the dominant environmental constraint in glacial equatorial lowland environments must be viewed with caution.

\section{ACKNOWLEDGMENTS}

This research was completed while holding a Smithsonian Postdoctoral Fellowship at the Smithsonian Tropical Research Institute, Republic of Panama. Thanks to Herman Behling, Paul Colinvaux, Henry Hooghiemstra, John Pandolfi, and Dolores Piperno for constructive criticism. H. Behling and E. Moreno gave invaluable assis- tance with pollen identification and laboratory techniques. This work was supported by NSF grant ATM 8709685.

\section{REFERENCES}

Absy, M.L., 1979. A Palynological Study of Holocene Sediments in the Amazon Basin: Manaus (Inst. Nacional de Pesquisas da Amazônia).

1985. Palynology of Amazônia: the history of the forest as revealed be the palynological record. In Prance, G.T., and Lovejoy, T.E. (Eds.), Key Environments: Amazônia: Oxford (Pergamon Press), 72-82.

Absy, M.L., Cleef, A., Fournier, M., Martin, L., Servant, M., Siffedine, A., Ferriera da Silva, M., Soubies, S., Suguio, K., Turcq, B., and Van der Hammen, T., 1991. Mise en evidence de quatre phases d'ouverture de la forêt dense dans le sud-est de l'Amazonie au cours des 60000 dernières années. Première comparaison avec d'autres régions tropicales. $C$. $R$. Acad. Sci. Ser. 2, 312:673-678.

Bartlett, A.S., and Barghoorn, E.S., 1973. Phytogeographic history of the Isthmus of Panama during the past 12,000 years (a history of vegetation, climate, and sea-level change). In Graham, A. (Ed.), Vegetation and Vegetational History of Northern Latin America: Amsterdam (Elsevier), 203-229.

Bird, M.I., Fyfe, W.S., Pinheiro-Dick, D., and Chivas, A.R., 1992. Carbon isotope indicators of catchment vegetation in the Brazilian Amazon. Global Biogeochem. Cycles, 6:293-306.

Brown, K.S., Jr., 1987. Soils and vegetation. In Whitmore, T.C., and Prance, G.T. (Eds.), Biogeography and Quaternary History in Tropical America: Oxford (Oxford Science Publ.), 19-45.

Bush, M.B., 1991. Modern pollen-rain data from South and Central America: a test of the feasibility of fine-resolution lowland tropical palynology. The Holocene, 1:162-167.

, 1994. Amazonian speciation: a necessarily complex model. $J$. Biogeogr., 21:5-17.

Bush, M.B., and Colinvaux, P.A., 1990. A long climatic and vegetation record from lowland Panama. J. Veg. Sci., 1:105-118.

Bush, M.B., Colinvaux, P.A., Wiemann, M.C., Piperno, D.R., and Liu, K.B., 1990. Late Pleistocene temperature depression and vegetation change in Ecuadorian Amazonia. Quat. Res., 34: 330-345.

Caratini, C., Bellet, J., and Tissot, C., 1975. Étude microscopique de la matière organique: palynologie et palynofaciès. In Coubas, A., and Pelet, R. 
(Eds.), Géochimie des Sédiments Marins Profonds. Orgon II, Atlantique, N.E. Brésil: Paris (Ed. Cent. Nat. Rech. Sci.), 157-178.

Cisowski, S.M., 1995. Synthesis of magnetic remanence correlation, Leg 155. In Flood, R.D., Piper, D.J.W., Klaus, A., et al., Proc. ODP, Init. Repts., 155: College Station, TX (Ocean Drilling Program), 701-702.

Clarke, K.R., 1993. Non-parametric multivariate analyses of changes in community structure. Aust. J. Ecol., 18:117-143.

Clarke, K.R., and Warwick, R.M., 1994. Change in Marine Communities: an Approach to Statistical Analysis and Interpretation: Plymouth (National Environmental Research Council, Plymouth Marine Laboratory).

Colinvaux, P.A., 1987. Amazon diversity in the light of the paleoecological record. Quat. Sci. Rev., 6:93-114

Colinvaux, P.A., Lui, K.-B., De Oliviera, P., Bush, M.B., Miller, M.C., and Kannan, M.S., 1996. Temperature depression in the lowland tropics in Glacial times. Clim. Change, 32:19-33.

Colinvaux, P.A., Olson, K., and Liu, K., 1988. Late-glacial and Holocene pollen diagrams from two endorheic lakes of the Inter-Andean Plateau of Ecuador. Rev. Paleobot. Palynol., 55:83-99.

Coutinho, L.M., 1990. Fire in the ecology of the Brazilian cerrado. In Goldammer, J.G. (Ed.), Fire in the Tropical Biota: Ecosystem Processes and Global Challenges: Berlin (Springer-Verlag), 82-105.

Dillehay, T.D., 1989. Monte Verde: a Late Pleistocene Settlement in Chile (Vol. 1): Washington, DC (Smithsonian Inst. Press).

Flood, R.D., Piper, D.J.W., Klaus, A., et al., 1995. Proc. ODP, Init. Repts., 155: College Station, TX (Ocean Drilling Program).

Germeraad, J.H., Hopping, C.A., and Muller, J., 1968. Palynology of Tertiary sediments from tropical areas. Rev. Palaeobot. Palynol., 6:189-348.

Geyer, W.R., Beardsley, R.C., Candela, J., Castro, B.M., Legeckis, R.V., Lentz, S.J., Limeburner, R., Miranda, L.B., and Trowbridge, J.H., 1991. The physical oceanography of the Amazon outflow. Oceanography, 4:814.

Gregory, W.A., and Hart, G.F., 1992. Towards a predictive model for the palynological response to sea-level changes. Palaios, 7:3-33.

Grimm, E., 1988. Data analysis and display. In Huntley, B., and Webb, T. (Eds.), Vegetation History: Dordrecht (Kluwer), 43-76.

Guidon, N., and Delibrias, G., 1986. Carbon-14 dates point to man in the Americas 32,000 years ago. Nature, 321: 69-771.

Guilderson, T.P., Fairbanks, R.G., and Rubenstone, J.L., 1994. Tropical temperature variations since 20,000 years ago: modulating interhemispheric climate change. Science, 263:663-665.

Haffer, J., 1969. Speciation in Amazonian forest birds. Science, 165:131137.

Hansen, B.C.S., Wright, H.E., Jr., and Bradbury, J.P., 1984. Pollen studies in the Junin area, central Peruvian Andes. Geol. Soc Am. Bull., 95:14541465.

Heusser, L.E., and Shackleton, N.J., 1994. Tropical climatic variation on the Pacific slopes of the Ecuadorian Andes based on a 25,000-year pollen record from deep-sea sediment core Tri 163-31B. Quat. Res., 42:222225 .

Heusser, L.E., and Stock, C.E., 1984. Preparation techniques for concentrating pollen from marine sediments and other sediments with low pollen density. Palynology, 8:225-227.

Hoffecker, J.F., Powers, W.R., and Goebel, T., 1993. The colonisation of Beringia and the peopling of the New World. Science, 259:46-53.

Hooghiemstra, H., 1984. Vegetational and climatic history of the high plain of Bogota, Colombia: a continuous record of the last 3.5 million years [Ph.D. thesis]. Dissert. Botan., 79.

Hooghiemstra, H., and Ran, E.T.H., 1994. Late and middle Pleistocene climatic change and forest development in Colombia: pollen record Funza II (2-158 m core interval). Palaeogeogr., Palaeoclimatol., Palaeoecol., 109:211-246.

Hooghiemstra, H., Stalling, H., Agwu, C.O.C., and Dupont, L.M., 1992. Vegetational and climatic changes at the northern fringe of the Sahara 250,000-5,000 years BP: evidence from 4 marine pollen records located between Portugal and the Canary Islands. Rev. Paleobot. Palynol., 74:153.

Hoorn, C., 1993. Marine incursions and the influence of Andean tectonics on the Miocene depositional history of northwestern Amazonia: results of a palynological study. Palaeogeogr., Palaeoclimatol., Palaeoecol., 105:267-309.

Hoorn, C., Guerrero, J., Sarmiento, G.A., and Lorente, M.A., 1995. Andean tectonics as a cause for changing drainage patterns in Miocene northern South America. Geology, 23:237-240.
Hope, G., and Tulip, J., 1994. A long vegetation history from lowland Irian Jaya, Indonesia. Paleogeogr., Paleoclimatol., Paleoecol., 109: 385-398.

Horn, S.P., 1985. Preliminary pollen analysis of Quaternary sediments from Deep Sea Drilling Project Site 565, western Costa Rica. In von Huene, R., Aubouin, J., et al., Init. Repts. DSDP, Washington (U.S. Govt. Printing Office), 533-547.

Irion, G., 1984. Sedimentation and sediments of Amazonian rivers and evolution of the Amazonian landscape since Pliocene times. In Sioli, H. (Ed.), The Amazon: Limnology and Landscape Ecology of a Mighty Tropical River and its Basin: Dordrecht (Junk), 201-214.

Kenkel, N., and Orlóci, L., 1986. Applying metric and non-metric multidimensional scaling to some ecological studies: some new results. Ecology, 67:919-928.

Kershaw, A.P., McKenzie, G.M., and McMinn, A., 1993. A Quaternary vegetation history of northeastern Queensland from pollen analysis of ODP Site 820. In McKenzie, J.A., Davies, P.J., Palmer-Julson, A., et al., Proc. ODP, Sci. Results, 133: College Station, TX (Ocean Drilling Program), $107-114$

Leyden, B., 1985. Late Quaternary aridity and Holocene moisture fluctuations in the Lake Valencia basin, Venezuela. Ecology, 66:1279-1295.

Lorente, M.A., 1986. Palynology and palynofacies of the Upper Tertiary in Venezuela. Diss. Bol., 99.

Lui, K., and Colinvaux, P., 1988. A 5200-year history of Amazon rain forest. J. Biogeogr., 15:231-248.

Lynch, T.F., 1990. Glacial-Age man in South America? A critical review. Am. Ant., 55:12-36.

Manley, P.L., and Flood, R.D., 1988. Cyclic sediment deposition within Amazon deep-sea fan. AAPG Bull., 72:912-925.

Martinson, D.G., Pisias, N.G., Hays, J.D., Imbrie, J., Moore, T.C., Jr., and Shackleton, N.J., 1987. Age dating and the orbital theory of the ice ages: development of a high-resolution 0 to 300,000-year chronostratigraphy. Quat. Res., 27:1-29.

Meade, R.H., 1994. Suspended sediments of the modern Amazon and Orinoco rivers. Quat. Intern., 21:29-39.

Meggers, B.J., 1984. The indigenous peoples of Amazonia, their cultures, land use patterns and effects on the landscape and biota. In Sioli, $\mathrm{H}$. (Ed.), The Amazon: Limnology and Landscape Ecology of a Mighty Tropical River and Its Basin: Dordrecht (Junk), 627-648.

Milliman, J.D., Summerhayes, C.P., and Barretto, H.T., 1975. Quaternary sedimentation on the Amazon continental margin: a model. Geol. Soc. Am. Bull., 86:610-614.

Minchin, P.R., 1987. An evaluation of the relative robustness of techniques for ecological ordination. Vegetatio, 69:89-107.

Muller, J., 1959. Palynology of Recent Orinoco Delta and Shelf sediments. Micropaleontology, 5:1-32.

Muller, J., Di Giacomo, E., and Van Erve, A.W., 1987. A palynological zonation for the Cretaceous, Tertiary, and Quaternary of northern South America. AASP Contrib. Ser., 19:7-76.

Nittrouer, C.A., Kuehl, S.A., Sternberg, R.W., Figueiredo, A.G., Jr., and Faria, L.E.C., 1995. An introduction to the geological significance of sediment transport and accumulation on the Amazon continental shelf. Mar. Geol., 125:177-192.

Piperno, D.R., Bush, M.B., and Colinvaux, P.A., 1990. Paleoenvironments and human occupation in late-glacial Panama. Quat. Res., 33:108-116.

Pires, J.M., and Prance, G.T., 1985. The vegetation types of the Brazilian Amazon. In Prance, G.T., and Lovejoy, T.E. (Eds.), Key Environments: Amazônia: Oxford (Pergamon Press), 109-145.

Prance, G.T., 1987. Vegetation. In Whitemore, T.C., and Prance, G.T. (Eds.), Biogeography and Quaternary History in Tropical America: Oxford (Oxford Science Publ.), 28-44.

Räsänen, M.E., Salo, J.S., and Jungner, H., 1991. Holocene floodplain lake sediments in the Amazon: ${ }^{14} \mathrm{C}$ dating and paleoecological use. Quat. Sci. Rev., 10:363-372.

Roosevelt, A.C., 1991. Moundbuilders of the Amazon; Geophysical Archaeology on Marajó Island, Brazil: San Diego (Academic Press).

Roubik, D.W., and Moreno J.E., 1991. Pollen and Spores of Barro Colorado Island. Monogr. System. Bot., 36.

Salgado-Labouriau, M.L., and Shubert, C., 1976. Palynology of Holocene peat bogs from the central Venezuelan Andes. Palaeogeogr., Palaeoclimatol., Palaeoecol., 19:147-156.

Salo, J., 1987. Pleistocene forest refuges in the Amazon: evaluation of the biostratigraphical, lithostratigraphical and geomorphological data. Ann. Zool. Fenn., 24:203-211. 
Salo, J., Kalliola, R., Häkkinen, I., Mäkinen, Y., Niemelä, P., Puhakka, M., and Coley, P.D., 1986. River dynamics and the diversity of Amazon lowland forest. Nature, 322:254-258.

Shipboard Scientific Party, 1995. Explanatory notes. In Flood, R.D., Piper, D.J.W., Klaus, A., et al., Proc. ODP, Init. Repts., 155: College Station, TX (Ocean Drilling Program), 47-81.

Showers, W.J., and Bevis, M., 1988. Amazon Cone isotopic stratigraphy: evidence for the source of the tropical meltwater spike. Palaeogeogr., Palaeoclimatol., Palaeoecol., 64:189-199.

Stanley, E.A., 1966. The problem of reworked pollen and spores in marine sediments. Mar. Geol., 4:397-408.

Stow, D.A.V., Howell, D.G., and Nelson, C.H., 1985. Sedimentary, tectonic, and sea-level controls. In Bouma, A.H., Normark, W.R., and Barnes, N.E. (Eds.), Submarine Fans and Related Turbidite Systems: New York (Springer), 15-22.

Stute, M., Forster, M., Frischkorn, H., Serejo, A., Clark, J.F., Schlosser, P., Broecker, W.S., and Bonani, G., 1995. Cooling of lowland tropical Brazil $\left(5^{\circ} \mathrm{C}\right)$ during the last glacial maximum. Science, 269:379-383.

Tissot, C., Dujwansah, M.R., and Marius, C., 1988. Evolution de le mangrove en Guyane au cours de l'Holocène: etude palynologique. In Caratini, C. (Ed.), Palynologie, Écologie, Paléoécologie: Actes du $X^{e}$ Symposium de L'Association des Palynologues de Langue Française: Pondichéry (Inst. Français de Pondichéry), 125-138.

Torres-Romero, J.H., 1988. Podocarpaceae. In Pinto, P., and Lozano, G. (Eds.), Flora de Colombia. Monograph No. 5. Univ. Nacional de Colombia.
Van der Hammen, T., 1963. A palynological study on the Quaternary of British Guiana. Leidse Geol. Meded., 29:125-180.

, 1974. The Pleistocene changes of vegetation and climate in tropical South America. J. Biogeogr., 1:3-26.

Van der Hammen, T., and Absy, M.L., 1994. Amazonia during the last glacial. Palaeogeogr., Palaeoclimatol., Palaeoecol., 109:247-261.

Van der Hammen, T., Duivenvoorden, J.F., Lips, J.M., Urrego, L.E., and Espejo, N., 1992. Late Quaternary of the middle Caqueta River area (Colombian Amazonia). J. Quat. Sci., 7:45-55.

Van der Hammen, T., and Gonzalez, A.E., 1960. Climate and vegetation history of the late glacial and Holocene of the Paramos de Palacio (Eastern Cordillera, Colombia, South America). Geol. Mijnbouw., 39:737-746. , 1965. Late glacial and Holocene pollen diagram from Cienaga del Visitador (dep. Boyaca, Colombia). Leidse. Geol. Meded., 32:193-201.

Van Geel, B., and Van der Hammen, T., 1973. Upper Quaternary vegetational and climatic sequence of the Fuquene area (Eastern Cordillera, Colombia). Palaeogeogr., Palaeoclimatol., Palaeoecol., 14:9-92.

Wijmstra, T.A., and Van der Hammen, T., 1966. Palynological data on the history of tropical savannas in Northern South America. Leidse. Geol. Meded., 38:71-90.

Date of initial receipt: 21 November 1995

Date of acceptance: 6 June 1996

Ms 155SR-225 
Appendix Table 1. Taxa recorded in palynological analysis of Amazon River, Continental Shelf, and Amazon Fan sediments.

\begin{tabular}{|c|c|c|c|}
\hline Taxa & $\begin{array}{l}\text { Ecological } \\
\text { group }\end{array}$ & Taxa & $\begin{array}{c}\text { Ecological } \\
\text { group }\end{array}$ \\
\hline Arboreal pollen & & Arboreal pollen cont. & \\
\hline Acalypha Euphorbiaceae & sg & Rubiaceae & \\
\hline Alchornea Euphorbiaceae & & Rutaceae & \\
\hline Alnus Betulaceae & $\mathrm{ca}$ & Sapindaceae & \\
\hline Anacardiaceae & & Sapium Euphorbiaceae & \\
\hline Annonaceae & & Sebastiana Euphorbiaceae & \\
\hline Apocynaceae & & Serjania Sapindaceae & \\
\hline Aspidosperma Apocynaceae & & Symmeria Polygonaceae & \\
\hline Bauhinia Leguminosae & & Symphonia Guttiferae & \\
\hline Bombacaceae & & Symplocos Symplocaceae & ca \\
\hline Byrsonima Malpighiaceae & & Tetrorchidium Euphorbiaceae & \\
\hline Cassia Leguminosae & & Trema Ulmaceae & sg \\
\hline Cecropia Moraceae & sg & Warszewiczia Rubiaceae & \\
\hline Celtis Ulmaceae & & Weinmannia Cunoniaceae & $\mathrm{ca}$ \\
\hline Cordia Ehretiaceae & & & \\
\hline Croton Euphorbiaceae & & Indeterminata & \\
\hline $\begin{array}{l}\text { Didymopanax Araliaceae } \\
\text { Elaeocarpaceae }\end{array}$ & sg & Non-arboreal pollen & \\
\hline Ericaceae & & Acaena Rosaceae & $\mathrm{ca}$ \\
\hline Esenbeckia Rutaceae & & Alternanthera Amaranthaceae & \\
\hline Euphorbiaceae & & Amaryllis Amaryllidaceae & \\
\hline Guarea Meliaceae & & Borreria Rubiaceae & \\
\hline Guettarda Rubiaceae & & Borreria Laevis Rubiaceae & \\
\hline Hedyosmum Chloranthaceae & ca & Chenopodiaceae/Amaranthaceae & \\
\hline Ilex Aquifoliaceae & & Compositae & \\
\hline Inga Leguminosae & & Cruciferae & \\
\hline Iriartea Palmae & & Cyperaceae & \\
\hline Leguminosae & & Eichhornia Pontederiaceae & a \\
\hline Loranthaceae & & Eryngium Umbellifera & \\
\hline Mabea Euphorbiaceae & & Gramineae & \\
\hline Malpighiaceae & & Ipomoea Convolvulaceae & \\
\hline Malvaceae & & Labiatae & \\
\hline Mauritia Palmae & & Ranunculus Ranunculaceae & ca \\
\hline Melastomataceae/Combretaceae & & Sagittaria Alismataceae & $\mathrm{a}$ \\
\hline Meliaceae & & Umbelliferae & \\
\hline Mimosa Leguminosae & & & \\
\hline Moraceae/Urticaceae & & Spores & \\
\hline Myrtaceae & & Anemia Schizaeceae & \\
\hline Onagraceae & & Blechnum Polypodiaceae & \\
\hline Palmae & & Cyatheaceae & \\
\hline Pera Euphorbiaceae & & Filicales & \\
\hline Piperaceae & sg & Grammatidaceae & \\
\hline Pithecellobium Leguminosae & & Hymenophyllaceae & \\
\hline Podocarpus Podocarpaceae & $\mathrm{ca}$ & Lycopodidaceae & \\
\hline Polygala Polygalaceae & & Osmunda Osmundaceae & \\
\hline Posoqueria Rubiaceae & & Selaginella Selaginellaceae & a \\
\hline Pouteria Sapotaceae & & & \\
\hline Proteaceae & & Reworked pollen and spores & \\
\hline Protium Burseraceae & & Grimsdalea Magnaclavata & \\
\hline Psuedobombax Bombacaceae & & Psilamonocolpites Spp. & \\
\hline Psychotria Rubiaceae & & Deltoidospora Spp. & \\
\hline Quercus Fagaceae & $\mathrm{ca}$ & Indeterminata & \\
\hline Rapanea Myrsinaceae & $\mathrm{ca}$ & Degraded \& Damaged & \\
\hline Rhizophoraceae & $\mathrm{m}$ & & \\
\hline
\end{tabular}

Notes: Many taxa are not exclusively within the arboreal or non-arboreal groupings, but are placed here within one or another on a subjective basis of probable affinity. Ecological groupings: $\mathrm{m}=$ mangroves; $\mathrm{ca}=$ cold-adapted taxa; $\mathrm{sg}=$ second-growth taxa; $\mathrm{a}=$ aquatic taxa. 
Appendix Table 2. Samples used in time horizon and species analysis.

\begin{tabular}{|c|c|c|c|c|c|}
\hline $\begin{array}{c}\text { Samples } \\
\text { (depth in } \mathrm{cm} \text { intervals) }\end{array}$ & $\begin{array}{l}\text { Depth } \\
\text { (mbsf) }\end{array}$ & $\begin{array}{l}\text { Concentration } \\
\left(\text { grain } / \mathrm{cm}^{3}\right)\end{array}$ & Lithologic unit & Channel-levee system & $\begin{array}{l}\text { Age } \\
\text { (ka) }\end{array}$ \\
\hline & & & & & A \\
\hline PC-4401 & 0 & 18,380 & composite mud & ? & $<5$ \\
\hline PC- 4218 & 6.8 & 18,780 & composite mud & ? & $<5$ \\
\hline PC-4220 & $2.4-5.9$ & 11,390 & composite mud & $?$ & $<5$ \\
\hline PC-4216 & $0.6-1.0$ & 14,160 & composite mud & - & $<5$ \\
\hline & & & & & B \\
\hline $\begin{array}{l}155-930 \mathrm{~B}-4 \mathrm{H}-\mathrm{CC} \\
155-931 \mathrm{~B}-2 \mathrm{H}-03,72-74\end{array}$ & $\begin{array}{r}34.75 \\
4.52\end{array}$ & $\begin{array}{r}27,090 \\
6600\end{array}$ & $\begin{array}{l}\text { Unit II, silty clay } \\
\text { Unit II, clay }\end{array}$ & $\begin{array}{l}\text { Amazon to Aqua } \\
\text { Amazon to Yellow }\end{array}$ & $\begin{array}{l}77.0 \\
18.0\end{array}$ \\
\hline $155-932 \mathrm{~A}-2 \mathrm{H}-02,51-55$ & 8.01 & 8710 & Unit II, clay & Amazon to $6 \mathrm{~A}$ & 17.0 \\
\hline 155-936A-7H-CC & 63.50 & 33,380 & Unit II, silty clay & Brown & 15.0 \\
\hline 155-938B-2Н-CC & 15.00 & 25,520 & Unit II, silty clay & Amazon to Purple & 18.0 \\
\hline $155-946 \mathrm{~A}-4 \mathrm{H}-\mathrm{CC}$ & 35.60 & 22,450 & Unit III, silty clay & ? & 15.9 \\
\hline & & & & & $\mathrm{C}$ \\
\hline 155-930C-12X-CC & 142.00 & 7510 & Unit II, silty clay & Orange & 38.0 \\
\hline 155-931B-14X-CC & 119.60 & 8190 & Unit II, silty clay & 5 & 32.0 \\
\hline $155-932 \mathrm{~B}-4 \mathrm{H}-\mathrm{CC}$ & 36.70 & 24,510 & Unit II, silty clay & $6 \mathrm{~A}$ & 49.5 \\
\hline 155-938A-16X-CC & 148.90 & 13,720 & Unit II, silty clay & 5 & 38.0 \\
\hline 155-946A-13H-CC & 117.40 & 20,190 & Unit III, silty clay & ? & 33.0 \\
\hline
\end{tabular}

Note: Ages derived from foraminifer and geomagnetic datums (see text and Table 2). PC = samples analyzed from the continental shelf adjacent to the Amazon Fan that are derived from muds taken from piston cores, and all date to within the last 5000 years (C. Nittrouer, pers. comm., 1994).

Appendix Table 3. Samples analyzed from Holes 932A and 946A.

\begin{tabular}{|c|c|c|c|c|}
\hline $\begin{array}{c}\text { Samples } \\
\text { (depth interval in } \mathrm{cm} \text { ) }\end{array}$ & $\begin{array}{l}\text { Depth } \\
\text { (mbsf) }\end{array}$ & $\begin{array}{l}\text { Concentration } \\
\left(\text { grains } / \mathrm{cm}^{3}\right)\end{array}$ & Lithologic unit & $\begin{array}{l}\mathrm{Ag} \\
(\mathrm{ka})\end{array}$ \\
\hline 155-932A-1 $\mathrm{H}$ (mudline) & $\underline{0.00}$ & -180 & Unit I, calcareous clay & $\leq 10$ \\
\hline $\begin{array}{l}155-932 \mathrm{~A}- \\
1 \mathrm{H}-3,44-46 \\
2 \mathrm{H}-2,51-55 \\
2 \mathrm{H}-4,67-71 \\
2 \mathrm{H}-\mathrm{CC} \\
3 \mathrm{H}-3,143-145 \\
3 \mathrm{H}-\mathrm{CC}\end{array}$ & $\begin{array}{r}3.44 \\
8.01 \\
11.20 \\
15.35 \\
19.93 \\
25.70 \\
\end{array}$ & $\begin{array}{r}12,780 \\
8710 \\
23,080 \\
37,790 \\
40,210 \\
30,510 \\
\end{array}$ & $\begin{array}{l}\text { Subunit IIA, } \\
\text { clay } \\
\text { silty clay }\end{array}$ & $\begin{array}{l}12.0 \\
17.0 \\
21.1 \\
26.2 \\
28.5 \\
36.3 \\
\end{array}$ \\
\hline $\begin{array}{l}4 \mathrm{H}-\mathrm{CC} \\
5 \mathrm{H}-\mathrm{CC} \\
6 \mathrm{H}-\mathrm{CC} \\
7 \mathrm{H}-\mathrm{CC} \\
8 \mathrm{H}-\mathrm{CC} \\
9 \mathrm{H}-\mathrm{CC} \\
10 \mathrm{H}-\mathrm{CC} \\
11 \mathrm{X}-3,108-110 \\
11 \mathrm{X}-\mathrm{CC} \\
12 \mathrm{X}-\mathrm{CC} \\
13 \mathrm{X}-\mathrm{CC} \\
14 \mathrm{X}-\mathrm{CC} \\
15 \mathrm{X}-\mathrm{CC} \\
16 \mathrm{X}-\mathrm{CC} \\
17 \mathrm{X}-\mathrm{CC} \\
18 \mathrm{X}-\mathrm{CC} \\
\end{array}$ & $\begin{array}{r}34.85 \\
44.40 \\
54.00 \\
63.40 \\
68.45 \\
81.80 \\
91.40 \\
95.58 \\
98.60 \\
110.30 \\
117.30 \\
127.70 \\
137.60 \\
145.60 \\
155.90 \\
167.20 \\
\end{array}$ & $\begin{array}{r}16,000 \\
13,130 \\
35,980 \\
23,220 \\
22,900 \\
26,380 \\
27,500 \\
7070 \\
26,860 \\
19,200 \\
20,920 \\
23,360 \\
15,390 \\
13,420 \\
15,640 \\
13,020 \\
\end{array}$ & $\begin{array}{l}\text { Subunit IIB } \\
\text { silty clay }\end{array}$ & $\begin{array}{l}49.2 \\
67.9 \\
69.3 \\
70.6 \\
71.3 \\
73.1 \\
74.3 \\
74.9 \\
75.3 \\
76.9 \\
77.9 \\
79.3 \\
80.6 \\
81.7 \\
83.1 \\
84.6 \\
\end{array}$ \\
\hline $\begin{array}{l}155-946 \mathrm{~A}- \\
13 \mathrm{H}-\mathrm{CC} \\
\end{array}$ & 117.40 & 19,350 & Unit IIIC, silty clay & 33.0 \\
\hline $\begin{array}{l}\text { 155-946A- } \\
14 \mathrm{H}-\mathrm{CC} \\
15 \mathrm{H}-\mathrm{CC} \\
16 \mathrm{X}-3,120-123 \\
16 \mathrm{X}-\mathrm{CC}\end{array}$ & $\begin{array}{l}131.60 \\
137.40 \\
144.20 \\
149.00\end{array}$ & $\begin{array}{l}3150 \\
3670 \\
3920 \\
2570\end{array}$ & $\begin{array}{l}\text { Unit IV } \\
\text { silty clay and } \\
\text { calcareous clay }\end{array}$ & $\begin{array}{l}<105 \\
>105 \\
>105 \\
>105\end{array}$ \\
\hline
\end{tabular}

Note: Concentrations are derived from the total pollen sum (arboreal pollen, excluding mangroves and reworked pollen). Mudline sample not included in pollen diagram (Figs. 5, 6). 